\title{
Estimates of the Natural Rate of Interest and the Stance of Monetary Policies: A Critical Assessment
}

\author{
E.S. Levrero ${ }^{1}$ \\ Working Paper No. 88
}

January 2019

\begin{abstract}
Starting with the literature on the estimates of the natural rate of interest, this paper critically analyzes the modern practice of identifying the benchmark rate of monetary policy with an equilibrium or neutral interest rate reflecting "fundamental forces" unaffected by monetary factors. After briefly mentioning the determinants of the natural rate of interest in the NewKeynesian models, the paper discusses the different notions of it that we find in these models and the problems encountered when the natural rate is estimated. It states that these problems are not only related to the difficulties in distinguishing the kind and persistency of economic shocks, but pertain to theory, namely to model specification and the alleged independence of the average or normal interest rate from monetary policy. Following Keynes's suggestion regarding the monetary nature of interest rates, some final remarks will thus be advanced on their effects on prices and income distribution as well as on the objectives and stance of monetary policies.
\end{abstract}

\footnotetext{
${ }^{1}$ Enrico Sergio Levrero, Roma Tre University. Correspondence address: enricosergio.levrero@uniroma3.it.

I would like to thank the Institute for New Economic Thinking (INET) for a grant to support this research. I would also like to thank R. Ciccone, M. Molinari, C. Panico, R. Pariboni, W. Paternesi Meloni and M. Seccareccia for their useful suggestions.
} 
JEL Codes: E43; E52; E58; E13; E12; E11

Keywords: Natural rates of interest, Structural and semi-structural models, Monetary policies, Taylor-rule, Interest rates and income distribution 


\section{Introduction}

The notion of a natural or neutral interest rate appears once again to play a central role in the implementation of monetary policies. It is behind the reaction functions of the inflation targeting models and explicitly introduced in the various specifications of the Taylor rule. It is deemed to be a useful benchmark that monetary authorities should consider when targeting interest rates (see Bernanke and Mihov, 1998; Barsky, Justiniano and Melosi, 2014). As Greenspan stated in his 1993 Humphrey Hawkins testimony to the Congress, the stance of monetary policies should be judged by comparing actual interest rates with "an equilibrium interest rate, specifically the real rate level that, if maintained, would keep the economy at its production potential over time."

The theoretical underpinning of this view stems from Wicksell's analysis of the relation between the market and natural interest rates as restated in the so-called New-Keynesian theory that combines real-business-cycle stochastic dynamic general equilibrium models with imperfect competition and nominal rigidities (cf. Woodford, 2003). Here, at least in the short run, monetary policies are seen to affect the real economy because changes in the nominal interest rates would lead to a change in the real rates and therefore in aggregate real activity whenever a discrepancy emerges between the actual and "equilibrium" real interest rates. Likewise, a change in the latter that is not followed by a change in the same direction of the "market" interest rate is deemed to have analogous effects on inflation rate and activity levels.

Despite wide consensus on this approach, there seem to be empirical and theoretical faults both in determining the "equilibrium interest rate" and in assessing its relation with policy interest rates. First, while the "benchmark rate" ought to be based on sound theoretical foundations allowing a meaningful interpretation of its behavior, different definitions of it appear in the literature depending on different specifications of models and their assessed time horizons. Second, the possibility of multiple equilibrium real interest rates and of an influence of "market" interest rates on the "natural" rates is not taken into account or is denied by specific assumptions, even if this would undermine at the root the idea of a natural rate of interest as the guiding star for monetary policy. Third, the benchmark rate should be readily computable from observable economic data, but its counterfactual nature leads to a variety of estimate methods and results that recall the early criticism by Myrdal and Lindahl that Wicksell's natural rate is not an operational notion, in the sense that it is incapable of practical application. Finally, in both the theoretical models and estimate procedures, an inverse relation 
between interest rates and components of aggregate demand is advanced as well as between the former and the price level, although it is admitted that such relations are weak and doubtful. This further depreciates the operational usefulness of the natural rate of interest, as well as the validity of its estimates, such as the claims about its alleged fall in the last decades on the grounds that the decrease in the observed real rates was not associated with an increase in the inflation rate and the levels of activity.

Starting from the literature on the estimates of the natural rate of interest, the aim of this paper is to critically analyze the modern practice of referring to an equilibrium or neutral interest rate to assess the stance of monetary policies. Section 2 briefly discusses the determinants of the natural rate of interest and the main relationships that characterize New-Keynesian models. Section 3 analyses the methods used to estimate the natural rate of interest and the acknowledged problems that they encounter. Section 4 further examines these problems, both on theoretical and empirical grounds. Finally, following Keynes's suggestion regarding the monetary nature of interest rates, in Sections 5 and 6 some final remarks are offered on their effects on prices and income distribution as well as on the objectives and stance of monetary policies, taking as its reference point the monetary regimes as classified in the Radcliffe report.

\section{On definitions of the natural rate of interest}

The modern theory of central banking can be seen as focusing on four main propositions. The first is that Central Banks directly set interest rates rather than determining them by controlling monetary aggregates. The second is that the targeted interest rate should equal a "natural" rate in order to maintain price stability ${ }^{2}$ - a rate that would reflect the normal profitability of capital and assure (in traditional or neoclassical models) that output is at its potential level. ${ }^{3}$ Third, any discrepancy between the actual and natural interest rate is deemed to lead to price inflation that is different from the desired and expected one. If some kind of price rigidity is present, this also leads to a discrepancy between actual and potential output. Finally, although sometimes denied under the pressure of facts, monetary policies are conceived to be neutral in the longrun and monetary or market interest rates are held to tend towards the natural rate. In contrast to Keynes' idea of the monetary nature of interest rates, it implies that their trend will reflect "fundamental forces" that are not influenced by "monetary disturbances."

\footnotetext{
${ }^{2}$ Note that in a fiat money economy, it is usually identified with a constant low inflation rate.

${ }^{3}$ Since we focus on the modern theory of central banking here we do not consider those alternative models where a natural rate of interest shaped by real factors appears but these factors are different from those envisaged by the neoclassical theory.
} 
As known, the origin of this view is Wicksell's monetary theory (cf. Wicksell, 1898 and 1935) according to which "productivity and thrift" set the 'normal rate of interest', which equates the supply of and demand for savings when all the available resources are fully employed (cf. Wicksell, 1898: p. 102; and Wicksell, 1935: 193). However, since with the bank system loan capital may be different from savings, Wicksell states that the market rate of interest may differ from the natural rate. ${ }^{4}$ If it is lower than the latter, the consequent expected extra-profits will increase the demand for loans and therefore aggregate demand in nominal terms, which in turn determines a rise in prices the higher the elasticity of the monetary system is. ${ }^{5}$ In this respect, Wicksell (1898: 111 and 149; 1935: 198-99) also considers the possibility of forced savings because inflation may be unfavorable to fixed incomes and lower interest rates may favor capital deepening, which would imply that capital profitability adapts itself to the "market" rate of interest. Yet he did not deem these effects to be relevant and argued that the rise in prices will eventually lead to an increase in the interest rates until a situation of stable prices, primarily of consumption goods, prevails (Wicksell, 1935: 202-4 and 207).

Wicksell's analysis represented the basis for the theories of credit cycles as driven by adjustment lags in relative prices (cf. e.g. Hayek, 1933 and 1935), and in this form it has been restated by the New-Keynesian models which are the workhorse of today's monetary policy analysis (cf. Clarida et al., 1999; Gali, 2015; Woodford, 2003). Both the introduction of nominal rigidities into the real business-cycle paradigm and the assumption of rational expectations, as well as the idea that Central Banks set interest rates with the amount of circulating money determined endogenously, in fact bring these models closer to Wicksell's analysis rather than to those founded on some kind of monetary illusion. ${ }^{6}$ However, there are

\footnotetext{
${ }^{4}$ According to Wicksell, the bank system tends to behave in a routine and conservative way, leaving the interest rates unchanged when a change in the natural rate occurs, for instance due to technical progress. He thus advanced an "exogenous" explanation of the discrepancy between the market and natural interest rates unlike, for instance, von Mises who argued that credit cycles stem from the tendency of Central Banks to lower interest rates below the natural ones.

${ }^{5}$ Wicksell maintains that this elasticity increases with bank concentration, the issuing of bills and notes and the development of clearing methods. He thought, however, that rising prices would eventually lead to an increase in interest rates because the demand for cash holdings impinges on its supply (cf. Wicksell, 1898: 110) and the profit margins of the bank system will otherwise begin to shrink. The (temporary in nature) previous investment decisions will thus be reverted to the normal amount determined by the natural rate of interest, namely by the interest rate that is expected when choosing the cost-minimizing technique.

${ }^{6}$ Both Pigou and Fisher before Friedman explained trade cycles by referring to money illusion. Thus, according to Fisher (1930: 285), an increase in money supply will lead to an increase in prices and profits, but initially the rate of interest does not increase because the fact that borrowers are able to pay higher interest rates is not understood. The consequent extra-profits will lead to a rise in the demand for loans and therefore the interest rate begins to increase, which also explains, according to Fisher, the Gibson paradox, namely the co-movement of interest and prices (Fisher, 1930: 282).
} 
also some differences with Wicksell's theory, in particular concerning the notion of the natural rate of interest, that are relevant, especially when discussing what the benchmark rate for monetary policies should be. In the New-Keynesian models, agents bear in mind how the monetary authority is likely to react to macroeconomic developments and this, in turn, influences their own actions today. Second, they dynamically optimize in a world characterized by stochastic shocks and various imperfections in the labor and commodities markets, which leads to various possible definitions of the natural rate of interest that differ from that advanced by Wicksell.

To grasp these differences and be able to discuss the different methods used to estimate what is viewed as the "benchmark rate" for monetary policies, let us recall the main equations that characterize the New-Keynesian models.

A first equation representing aggregate supply captures the wage bargaining process ${ }^{7}$ and the price-setting behavior of firms that results from profit-maximization obstructed by some sort of nominal rigidity. Owing to this rigidity, firms have to take into account the expected development of prices over the next period when setting their prices today. In its most basic form, as a first linear approximation of the relations that represent firm optimality conditions, this equation is known as the 'New-Keynesian Phillips curve' which expresses current inflation $\pi_{t}$ as a function of currently expected inflation for the next period $E \pi_{t+1}$, the current output gap $x_{t}$, and (cost-push) shocks on desired mark-ups in the commodities and labor markets $\lambda_{t}$

$[1] \pi_{t}=\beta E \pi_{t+1}+k x_{t}+\lambda_{t}$

where the parameter $\beta$ denotes the (uniform) subjective discount rate of households, ${ }^{8} k$ incorporates the degree of nominal price rigidity, ${ }^{9}$ and the output gap is the difference between actual output and its natural level, that is, the production level that would prevail in the hypothetical situation of fully flexible prices and perfect information. According to this

\footnotetext{
${ }^{7}$ In several models, households act as price setters in the labor market and wages can only be optimally adjusted when a random "wage change signal" is received.

${ }^{8}$ Typically, households are the owners of firms, representative agents are assumed and there are complete financial markets.

${ }^{9}$ The value of $k$ depends on the fraction of firms that adjust price in any period and from the strategic complementarity between them. A higher value of $k$ would imply a smaller elasticity of output to unexpected changes in nominal expenditure. Together with the demand elasticity for monopolistic firms and the inverse of Frisch elasticity of labor supply, it shapes the slope of the Phillips Curve.
} 
equation, in the short run there is a trade-off between output and inflation, which is also influenced by cost push shocks primarily due to the time-varying market power of firms.

The second equation stems from the assumption that, given their preferences and intertemporal budget constraint, households optimize their whole consumption stream over the present and the future so that in equilibrium at the margin, there is no increase in their utility by reducing present consumption by one unit in order to increase future consumption. Starting from the Euler equation, ${ }^{10}$ when assuming a specific form for household preferences, this leads to an expression that relates present consumption to future consumption and the rate of interest according to households' inter-temporal elasticity of substitution $\sigma .^{11}$ Comparing the expression obtained for the actual real rate of interest with the hypothesized rate at its natural level, the dynamic $I S$ curve is thus advanced (cf. e.g. Clarida et al, 1999), where the current output gap depends on the currently expected output gap of the next period $E_{t}\left[x_{t+1}\right]$, elasticity $\sigma$ and the interest rate gap $i_{t}-E_{t}\left(\pi_{t+1}\right)-r_{t}^{n}$

$[2] x_{t}=E_{t}\left[x_{t+1}\right]-\frac{1}{\sigma}\left\{\left[i_{t}-E_{t}\left(\pi_{t+1}\right)\right]-r_{t}^{n}\right\}$

In a closed economy, the equation also reflects investment decisions by the firms that choose the amount of capital stock to be installed, which maximizes profits. ${ }^{12}$ In the New-Keynesian models, investments are in fact put in an inverse relation to the interest rate and a direct relation to output changes, adding lags to achieve the optimal capital-output ratio in the presence of adjustment costs (see e.g. Jorgenson, 1963 and 1967). ${ }^{13}$

The natural rate of interest enters at this stage of analysis, stemming from the Euler intertemporal equation when output is at its natural or efficient level. ${ }^{14}$ It is fixed as the one-period equilibrium real rate of return that would prevail in the hypothetical equilibrium with flexible prices, that is, in the absence of nominal price rigidities. It is affected solely by real factors

\footnotetext{
${ }^{10}$ This arises from first order conditions of constrained utility maximization and states that the marginal utility of consumption at time $t$ is equal to $(1+r) /(1+\beta)$ times its marginal utility at time $t+1$, where $r$ is the rate of interest and $\beta$ is the rate of inter-temporal preference, namely a household's preference to anticipate consumption.

${ }^{11}$ The interest rate will in fact influence consumption according to income, wealth and substitution effects.

12 The New-Keynesian models usually have Cobb-Douglas or CES production functions.

${ }^{13}$ In the DSGE models utilised by the Central Banks to forecast the effects of monetary policies and the natural rate of interest, the public sector and the "rest of the world" are also taken into account in addition to households, firms and the monetary policy maker (cf. e.g. Bank of England, 2013; Del Negro, Giannnoni and Schorfheide, 2015). Therefore, equation 2 would also reflect the negative effects on net exports of an appreciation of the real exchange rate driven by an increase in the interest rate.

${ }^{14}$ Unlike in Solow's growth model where $r^{n}=\alpha(n+q+d) / s, \alpha$ is capital elasticity, $n$ is the population growth rate, $q$ is the rate of growth of labor productivity, $d$ is the depreciation rate and $s$ is the propensity to save, this latter variable is determined by inter-temporal utility maximization as in the Ramsey-Cass-Koopmans model.
} 
such as technical progress, the growth of the workforce, the time preference of households and movements in government expenditure, mirroring over time the dynamics of these driving forces. Following Holston, Laubach and Williams (2016), we can write

$$
\text { [3] } r_{t}^{n}=E_{t}\left[c g_{t+1}\right]+E_{t}\left[z_{t+1}\right]
$$

where $c$ is the reciprocal of the inter-temporal elasticity of substitution, $g$ is the output natural rate of growth and $z$ synthesizes the other factors influencing the natural rate of interest including the rate of temporal preference. ${ }^{15}$

However, assuming temporary real shocks away from balanced growth, different notions of the natural rate of interest are taken into account when analyzing its estimation procedures and prescriptions for monetary policies. These reflect its reference to conditions of perfect or imperfect competition in the commodities and factor markets as well as transitory or only permanent components of the natural rate. We find in fact in the literature:

1) an efficient rate of interest (cf. e.g. Curdia, 2015) which is subject to temporary as well as permanent movements and prevails when nominal prices are flexible and output is at its efficient level, namely at the level achievable when all markets are not distorted by any monopolistic power;

2) a natural rate of interest which like (1) is subject to temporary fluctuations due to temporary shocks and manifests itself when nominal prices are flexible and output is at its natural rate, which now also reflects, however, a given degree of imperfection in the commodities and labor markets (cf. e.g. Woodford, 2003: 152 and 251); ${ }^{16}$

3) a long-run natural rate that corresponds to potential output for a given degree of market imperfections when both causal shocks and lags of adjustment are averaged out;

4) Wicksell's long-run notion of the natural rate of interest, which correspond to (3) but in a condition of free competition.

The first two definitions of the natural rate in particular differentiate the current models for monetary policies from Wicksell's analysis of the relation between the market and natural rates of interest. Another relevant difference is that in these models, unlike in Wicksell, inflation is also influenced by expected interest rate gaps and is an equilibrium phenomenon since all

\footnotetext{
15 The specific relationship shaping the natural rate of interest depends on the assumptions of the model on household preferences, their degree of altruism, the influence of habit formation and the weight of liquidity constrained households (for whom current rather than future income is relevant for present consumption). For examples of this class of models, see Christiano et al. (2005), Smets \& Wouters (2007), Giammarioli \&Valla (2003).

${ }^{16}$ In this respect, even if possible, shocks on the mark-ups are usually excluded from those temporarily affecting the natural rate and the analysis concentrates on other supply as well as demand shocks.
} 
variables are consistent with the optimality conditions of forward-looking households and firms. More precisely, looking at equations [1] and [2], the equilibrium inflation rate and the current output gap may be expressed as a function of the sum of current and expected interest rate gaps and therefore as a forward-looking variant of the Wicksellian analysis (cf. Woodford, 2003: 279).

Since any discrepancy between the actual and the natural rate of interest leads to a change in the inflation rate and in the level of output relative to its steady state value, in order to stabilize prices and output, the resulting rule for monetary policy is that authorities should credibly commit themselves to following the natural rate of interest and reacting to unfavorable situations. The monetary policy reaction function that is usually advanced in the NewKeynesian models to assure a nominal anchor for $\operatorname{prices}^{17}$ is the Taylor rule according to which monetary authorities should set short-term interest rate $i_{t}$ at the level

[4] $i_{t}=r_{t}^{n}+E_{t}\left[\pi_{t+1}\right]+a_{\pi}\left(\pi_{t}-\pi^{T}\right)+a_{y}\left(y_{t}-y_{p}\right)$

thus reacting, for a given natural rate $r_{t}^{n}$, to any deviation of the actual inflation rate from the target one $\pi^{T}$, as well as of the actual output $y$ from the potential one $y_{p}$, namely of the output gap $x_{t}$ from zero. ${ }^{18}$

If, however, the natural rate of interest moves over time due to exogenous factors (namely, due to changes in the real factors behind equation [3]), the resulting interest rate gap will vary and therefore the output gap will not be stabilized according to the "demand equation" [2] unless monetary authorities forecast the natural or neutral ${ }^{19}$ rate of interest. ${ }^{20}$

\footnotetext{
17 As noted by Woodford (2003: 69) "[t]he predictions of the neo-Wicksellian theory [are not] really (....) different from those of a standard quantity-theoretic analysis" when the Taylor principle is introduced to avoid price indeterminacy (cf. also Bullard and Mitra, 2002).

${ }^{18}$ A debate exists, however, regarding whether the Taylor rule really explains the behavior of Central Banks. Curdia et al. (2015) for instance refers to a W rule according to which the monetary authority only reacts to inflation rates.

${ }^{19}$ It is stated that this would conform to Keynes's reference in the General Theory (1936) to a 'neutral' rate of interest that is 'consistent with full employment, given the other parameters of the system'. However, as will be specified below, if this remark stemmed from some neoclassical elements that were still present in his analysis, Keynes emphasised the monetary nature of the interest rate and did not ascribe unemployment to nominal price rigidities as in the New-Keynesian models.

${ }^{20}$ However, cost-push shocks would deny full stabilisation (cf. Benigno \& Woodford, 2005) since, if the monetary authority raises the interest rate to counterbalance their effect on inflation, this would generate a negative output gap. In this case, the weights that the Central Bank attaches in its loss function to both targets would come into play.
} 
As recalled above, different rates are considered in this regard. According to Blinder (1998: 32), the natural rate should be that which is settled by the steady state IS curve when all the lags and random shocks disappear and output is at its (long run) potential level. Since it is difficult to estimate and impossible to know precisely, it would be more a concept than a number, a way to think about monetary policy rather than a rule (Blinder, 1998: 33). ${ }^{21}$ Monetary authorities should therefore estimate different models and compute the average ex post real interest rate for long periods in order to have an idea of the stance of monetary policy, assuming that lags and causal shocks average out. ${ }^{22}$

The notion considered in New-Keynesian models is however a "short-run" natural rate of interest that varies (usually pro-cyclically) during the cycle. More than Wicksell, it resembles Robertson's prescriptions for monetary policies to follow the shifts of the demand for and supply of loanable funds during the cycle in order to determine the benchmark rate for monetary policy. ${ }^{23}$ Robertson (1962) calls it a "quasi-natural" rate of interest towards which the monetary rate should tend since the immediate settlement of the interest rate to its normal level would otherwise harm economic activity.

To give an example, consider Figure 1 where a permanent shift of the IS curve from $I S_{1}$ to $I S_{2}$ takes place. If the monetary authorities do not change the interest rate, output will fall to $Y_{l}$ below its potential level $Y_{p}$. If at this point a temporary shift of the IS curve on the left occurs due to an increase in the propensity to save and a decrease of firm willingness to invest during the crisis, the settlement of the rate of interest to the new normal rate $i_{n 2}$ will not assure output that comes back to its potential level. The benchmark of monetary authorities should indeed be the quasi-natural rates of interest $i_{q n 1}$ and $i_{q n 2}$, taking into account the temporary shifts of the $I S$ curve due to temporary shocks. On the other hand, the work of the monetary authorities may be complicated further by the fact that also the potential output $Y_{p}$ may change during the cycle. As Robertson observed, "[n]ormality, and its symbol the 'natural rate of interest', seem to be like a path which is plain enough to see while you are treading it, but which is

\footnotetext{
${ }^{21}$ This is the reason why Central Banks should change the rate of interest slowly, for instance by a rule according to which $i_{t}=\vartheta_{1} i_{t-1}+\left(1-\vartheta_{1}\right)\left[\vartheta_{2} \frac{1}{4} \sum_{j=0}^{3} \pi_{t-j}+\vartheta_{3} x_{t}+u_{t}\right]$. See also below, pp. 16-17.

${ }^{22}$ Blinder specifies that unrepresentative periods should be excluded from the average, such as the 1970s when real short-term interest rates became negative or the 1980s when they were exceptionally high. Considering these averages for $30-50$ years, we would get a value between 1.75 and 2.25 per cent as the normal or neutral rate of interest. On this basis, Blinder judged the stance of US monetary policy. For instance, it would have been accommodative in the years 1990-1, when the real rate of interest approached zero, which "is well below the neutral rate by anyone's reckoning" whereas it would have been restrictive around 1994-95 and neutral around 1997.

${ }^{23} \mathrm{~A}$ similar concept also appears in the final chapters of Keynes's Treatise on Money (cf. Panico, 1988).
} 
exceedingly difficult to rediscover once you have strayed away from it" (Robertson, 1962: 114).

Robertson's acknowledgment of the instability of the rate equating savings and investment when output is at its potential level poses a real challenge for monetary policies following the prescriptions of New-Keynesian models. It adds to the complications arising from the variability across estimation methods and the unavoidable uncertainty surrounding any statistical estimate. A clear example comes from the experience of the recent crisis. While the rule as originally advanced by Taylor, which ignores the "quasi-natural" rates of interest, would have prescribed not lowering the short-term interest rate quickly since this policy is too accommodative, a slow decrease in the policy rates would be seen as being insufficient to stimulate economic activity if the natural rate were to fall during the crisis.

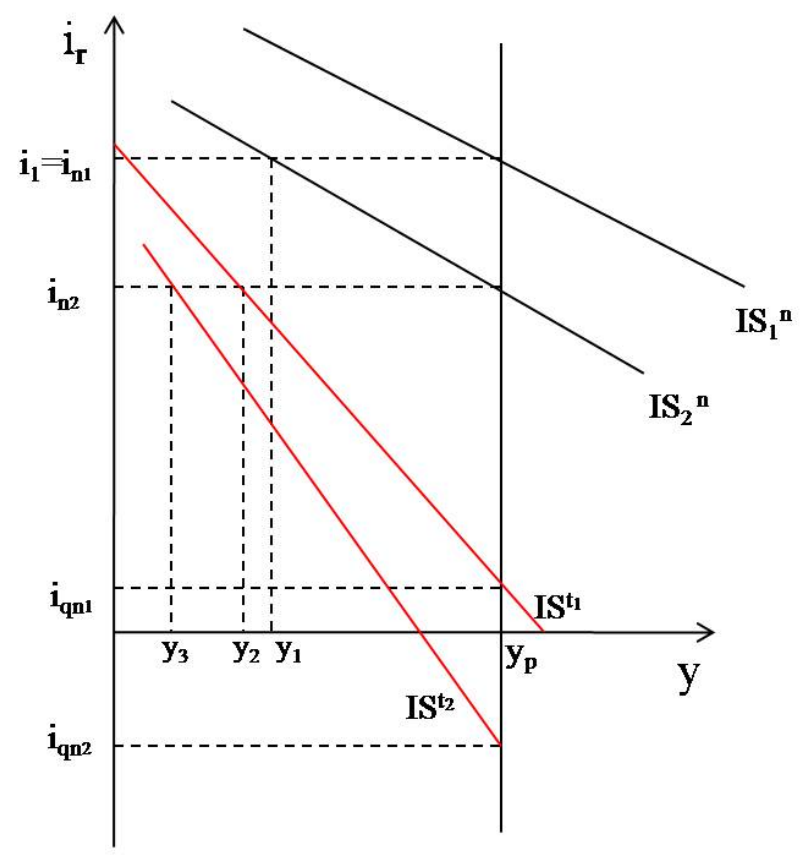

Figure 1: Robertson's quasi-natural and natural rates of interest

\section{The estimates of the natural rate of interest}

In what has been stated above, there is no clear indication of how to infer the natural rate of interest (NRI from here on) that should be the optimum rate for stabilizing the economy and should guide monetary policy according to the modern theory of central banking. We will now briefly consider the main estimation procedures that are used in this respect and then move on to assess the robustness and validity of the notion of the NRI as a benchmark rate for monetary policies. 
We can group the various approaches to estimating the NRI into three main categories: (i) time-series approaches; (ii) fully-fledged equilibrium models with a microeconomic base; and (iii) semi-structural econometric models with the NRI as a latent variable. ${ }^{24}$ Additionally, financial market information has been exploited to obtain estimates of the NRI, e.g., by using data on inflation-indexed bonds ${ }^{25}$ or by employing a consumption-based asset pricing approach (see Giammarioli and Valla, 2004).

Considering group (i), that undervalues the shifts in the NRI, the idea is to estimate this rate by using (local) trends of realized real rates under the assumption that in the long-run-that is, after all shocks have run their course - the actual real rate should have converged to its natural counterpart.

To ascertain these trends, different statistical methods are used: moving averages of actual real rates over the typical length of a business cycle, other weighting schemes, and the filtering out of low-frequency components from the real interest rate. ${ }^{26}$ The weaknesses related to these methods include the need to choose the type of price index and ex ante or ex post measures of inflation, the decision regarding the 'window width' over which the sequence of means is computed, and the fact that methods based on local averaging typically yield a fairly smooth time series. For this latter reason in particular, the resulting time-series for the NRI are seen as only rough estimates of it because, as averages, they do not share the characteristic of the theoretical concept of a rate that is possibly subject to ample and persistent variations that correspond to the size and dynamics of the real shocks the NRI depends on. By their very nature, these estimates would in fact translate to a de facto abrupt persistent upward change in

\footnotetext{
${ }^{24}$ It has been a natural development of the NRI as the time invariant intercept of the Taylor rule in an identified structural VAR (cf. Rotemberg \& Woodford, 1997) where potential output and the NRI are taken as known in order to identifying the shocks of monetary policies. According to Rudebusch (2001), the monetary authorities would in fact do their "experiments" using an average rate of interest but facing a variable IS curve in each period.

${ }^{25}$ Here the idea is that long-term interest rates embody expectations regarding future short-term rates and that the latter are linked to "equilibrium" rates (cf. Bernanke and Blinder, 1992). Therefore, if the yields curve steepens, the short-term interest rate will be lower than the natural rate, whereas if it flattens, the opposite will be true. However, as Bomfin (2001) acknowledges, long-term interest rates may vary for reasons not linked to changes in the differentials between actual and equilibrium short-rate interest rates, for instance, due to inflation expectations that can lead to higher long-term rates even if the underlying real rates are unchanged. Furthermore, even if inflation-indexed bonds are considered, the problem remains of possible distortions due to liquidity premium, term and risk premiums, irrational expectations, and the fact that only short series exist for these rates. Cf. also Blinder (1998: 71) who stressed that forward rates implicit in the long-term rates are poor forecasters of future rates.

${ }^{26}$ Laubach and Williams (2003) and Wu (2005) provide an application of Hodrick-Prescott and band-pass filters to estimate the natural rate of interest while Crespo, Cuaresma et al. (2004) and Hamilton and others (2015) use multivariate techniques to decompose trend and cycle.
} 
the NRI into a smooth phase of transition. Moreover, even if the NRI is allowed to shift over time, real interest rates are mean reverting, especially outside some specific thresholds (for instance $\pm 5 \%$ in Hamilton, Harris and others, 2015).

The merit of this kind of analysis is that it starts from the proprieties of the time-series rather than imposing a theoretical structure to begin the analysis (cf. in this regard, Lavoie, 2014). However, if the trend variable has to be interpreted as a natural rate of interest, we should exclude the fact that the effective and natural real rates would be able to diverge for long periods which, according to the New-Keynesian model sketched above, is not the case when phases of accelerating or decelerating inflation rates are observed. ${ }^{27}$ It is thus argued that a model is necessary to estimate an unobserved variable such as the NRI since it is an abstraction that may be inferred only by the way in which it works. ${ }^{28}$

Moving on therefore to group (ii), the model-based computations of the NRI refer to the above-mentioned New-Keynesian DSGE model (cf. Gali, 2015; Justiniano and Primicerio, 2010; Woodford, 2003) and highlight short-run or quasi-natural rates of interest. The model would represent in detail the real factors affecting the interest rates and requires a measurement of variables which themselves are partly or completely unobservable, such as the time discounting rate of private households. The natural rate is estimated indirectly, making use of interactions between the relations described by the model and the current and past observations of directly observable economic data. The model makes it possible to emulate the hypothetical flexible-price path of the economy, that is, the sequence of equilibria in which all real variables are at their natural levels, and this counterfactual exercise allows the evolution of the natural rate of interest to be derived as a function of shocks on preferences and technology (see Barski, Justiniano and Melosi, 2014; Giammarioli and Valla, 2003; Neiss and Nelson, 2003; Smets and Wouters, 2003; Smet and Wouters, 2007; Edge, Kiley and Laforte, 2008; Justiniano \& Primicerio, 2008; Curdia et al. 2015).

\footnotetext{
${ }^{27}$ Thus, the increasing inflation rates during the 1960s and 1970s would indicate a rate of interest that is lower than the natural one, whereas during the years of Volcker's disinflation, the opposite would have occurred. Univariate time series in particular could not control for this and would ascribe these patterns of the interest rate to its trend.

${ }^{28}$ As stated by Curdia (2015) "[o]ne can only say that if the bank policy succeeds in stabilising prices, the bank rate must have been brought in line with the natural rate." Note that the theoretical model may be different when considering emergent economies with financial deregulation, the NRI being the one that avoids speculative attacks on domestic currency.
} 
While this model-based approach is deemed to give a theoretical definition of the estimated parameters and the possibility to evaluate the optimality of monetary policies, nevertheless, various criticisms can and have been raised. Since it concentrates on de-trended series and the stance of monetary policies during the cycle, it emphasizes the "high frequency" movements of the NRI, namely the response of the natural rate to temporary shocks, rather than shifts of its average or its "lower frequency" movements (cf. Manrique and Marques, 2004). Moreover, estimates are strongly influenced by the hypotheses concerning the structural model (cf. Levin, Wieland and Williams, 2001), with the risk that the underlying, possibly narrow, view of economic interactions may not be an adequate representation of reality. Distorted pictures of real-world interactions would lead to distorted estimates of the NRI and the attempt to overcome this uncertainty regarding the model through different specifications of it would imply obtaining as a result different estimates of the same variable. For instance, a larger model that adds further mechanisms such as endogenous capital accumulation with adjustment costs, habit formation in consumption and the indexation of prices and wages ${ }^{29}$ would lengthen the time period in which the shocks influence the evolution of the economy and hence the estimated NRI around the steady state would become more volatile (cf. Edge, Kiley e Laforte, 2008). ${ }^{30}$ Moreover, this model enlargement would imply a greater need to use prior beliefs about the values of model parameters. ${ }^{31}$

The need to ascribe a greater weight to drifts of the "average" natural interest rate and to give more relevance to the data against the model is at the basis of the last main method used to estimate the NRI, that of the semi-structural approach developed by Laubach and Williams. Due to the difficulties in measuring the determinants of the natural rate of interest, this approach advances a parsimonious specification of the model that lowers the risk that the estimates of NRI will be influenced too much by structural parameters of badly specified relations. The NRI is thus obtained as an unobservable exogenous stochastic process by means of few structural relations and identification restrictions concerning equation [1]-[3] mentioned above (see e.g., Laubach and Williams, 2003;ECB, 2004; Garnier and Wilhelmsen, 2005; Cour-Thimann and others, 2006; Benati and Vitali, 2007; Mesonnier and Renne, 2007;

\footnotetext{
29 The augmented specification of the model may also imply distinguishing between residential and nonresidential investment, liquidity constrained and unconstrained households, durables and non-durable goods, and so on.

${ }^{30}$ Note that this volatility contrasts with the prudence of Central Banks in changing the rate of interest due to the awareness of the effect of this change on the stability of financial markets.

31 With this estimate method the NRI estimates are in fact influenced by prior beliefs regarding the deep parameters that shape, for instance, the slope of the IS and Phillips curves, such as the intertemporal elasticity of substitution, households discounting rate and the elasticity to wages of labor supply.
} 
Laubach and Williams; 2015; Holston, Laubach and Williams, 2016). The unobservable variable derives in fact here from adjusting it according to the difference between the model forecast of the output gap and its actual value. Therefore, if the output gap forecasted by the specified dynamic IS curve is greater than the actual one, the NRI is lowered. Likewise, if the inflation rate is lower than the value forecasted by the specified Phillips Curve, the potential output is raised $^{32}$ (see Appendix 1 for further details).

However, even the semi-structural approach is not without criticism. The standard errors for the NRI are relatively high and thus its estimates uncertain (cf. Laubach \& Williams, 2001: 12; Laubach \& Williams, 2003: 1063 and 1066; Wintr and others, 2005 for Europe). Moreover, restrictions on the variances in the natural growth rate, the potential output and the output-gap, as well as the hypotheses on the lag-structure (namely on shock propagation), are crucial to the results and may be queried on both theoretical and empirical grounds. As stressed by Lewis and Vasquez-Grande (2017), the strategy of estimation and the exact model specification highly influence the path of the NRI, as is the case of the coefficients ascribed to the unobservable determinants $g$ and $z$ of the NRI as outlined in equation [3]. ${ }^{33}$ Finally, while the approach does not distinguish between the different forces driving the NRI, it nevertheless imposes restrictions on the parameters used to identify the model. In particular, the sensitivity of the output gap to the interest rate must be negative and the slope of the Phillips Curve must be positive. ${ }^{34}$ As we will see below, these assumptions are questionable, like the simple relation advanced to identify the NRI. For instance, Hamilton, Harris \& others (2015) stressed in this respect that the influence on the NRI of the world output rate of growth and of exchange rate regimes should be considered and that there is great uncertainty over the value of the discount rate and the influence on consumption of the interest rate. Looking at the average real interest rates and output growth rates, they also stressed that there is no strict correlation

\footnotetext{
${ }^{32}$ As usual, the filtering out of the unobservable NRI from observable data will be more efficient if it is twosided, that is, if it uses not just past and current data, but also future data.

${ }^{33}$ See also equation [8] in Appendix 1. In particular, the variability of the NRI increases if the $\mathrm{z}$ process is not a random walk. With this hypothesis, the NRI would increase just after the 2008 crisis and be at 1.8 percent in 2016 in contrast to the non-recovery path estimated by Laubach and Williams.

${ }^{34}$ Looking at the model specified in Appendix 1, the coefficient $a_{r}$ of the IS curve [5] must be negative and the coefficient $b_{y}$ of equation [6] must be positive. Holston, Laubach \& Williams (2016) view these "as minimal priors on the structure of the model that, in the event, facilitate the convergence of the numerical optimization during estimation." They dictate that $b_{y}$ must be higher than or equal to 0.025 , and $a_{r}$ be lower than or at the most equal to -0.0025 .
} 
between these two variables (see idem, Figure 3.3. Cf. also Carrol \& Summer, 1991; Clark \& Kozicki, 2005; Bosworth, 2014). ${ }^{35}$

It may thus now be clearer why according to Blinder the NRI should be "more a concept than a number, a way to think about monetary policy rather than a rule" (cf. also Judd and Rudebusch, 1998; Bernanke et al, 1999). Apart from the theoretical limits that we will discuss in the next section, the variety and uncertainty of its value due to different concepts and methods of estimation cannot but lead to a prudent strategy by the Central Banks.

The estimates of the NRI in the recent crisis may provide an example in this regard. Looking at the data on real short-term interest rates, we see that they fell in the last two decades (cf. e.g. Rachel and Smith, 2015; Hamilton, Harris \& others, 2015). ${ }^{36}$ Unlike for the previous decades, this fall has been viewed as the result of a contemporaneous decrease in the natural rate of interest. While for the 1980-92 period, 90 per cent of the variance of actual short term rates would have stemmed from monetary policy shocks, ${ }^{37}$ subsequently their variability lowers and monetary policy would have been neutral (cf. Blanchard, Furceri, Pescatori, 2014). The natural rate of interest would have in fact passed from around 3-4 per cent in the 1980s to -0.5-0.5 percent in the years 2013-2016 (cf. Bean, Broda \& others, 2015; Fiorentini et al., 2018, Lubick \& Matthes, 2015; Laubach \& Williams, 2015; Holston, Laubach \& Williams, 2016; Hamilton \& others, 2015).

However, as Figures 2 and 3 show, the uncertainty surrounding the extent and timing of this fall is high among estimates, with a larger volatility of the NRI when using model-based and filtering methods than when using a semi-structural approach or peak-to-peak averages. As already stated above, this poses significant problems for monetary policy, ${ }^{38}$ especially in the

\footnotetext{
35 The possible existence of flat IS and PC curves, and thus of difficulties in these circumstances to identify the natural rate of interest, has led to adding in these cases in the semi-structural model the assumption of stationarity of the interest rate gap (cf. Fiorentini \& al., 2018) in order to assure that the observability matrix has rank equal to the number of the unobserved variables. The limit of this procedure is that a priori the flatness of the IS curve (with $y$ as the dependent variable) is ascribed precisely to a change in the natural rate of interest in the same direction and with the same intensity as the actual interest rate.

${ }^{36}$ Also real long-term interest rates fell. The average real interest rates on ten year government bonds for the G7 countries (excluding Italy) passed from $3-4 \%$ in the years $1987-1999$, to $1-3 \%$ in 2000 s, to $1-0.5 \%$ in the years 2000-2015, with even negative values in recent years (cf. King and Low, 2014). The premium on these bonds lowered due to quantitative easing and forex interventions facing the fall in the net supply of safe assets during the recent financial crisis (cf. King \& Law, 2014; Caballero \& Fahri, 2014).

${ }^{37}$ It is usually stated that the NRI was higher than the actual rates in the 1960s and 1970s and lower in the 1980s and 1990s. However, Orphanides (2001) contested Taylor's idea that before Volcker the Fed did not follow the principle of increasing the rate of interest more than inflation, thus determining macroeconomic instability.

${ }^{38}$ Another difficulty stems from the continuous revisions of the estimates which in the years 2008-2013 led to a progressive lengthening of the adjustment phase of the short natural rate to its long or steady state value.
} 
narrow context of the zero lower bound, and recalls the different notions of the NRI outlined at the end of Section 2. In actual fact, those who, like Taylor \& Weiland (2015), referred to a long-run notion of the NRI that would be in the US around 2.5-3 per cent (cf. also Hamilton, Harris \& others, 2015; Smet \& Wouters,

Figure 2: Estimated natural rates of interest

Data sources: Curdia (2015) and Holston, Laubach and Williams (2017)

Series 1: structural method

Series 2: semi-structural method (one-sided estimates)

Series 3 (grey line): semi-structural method (two-sided e

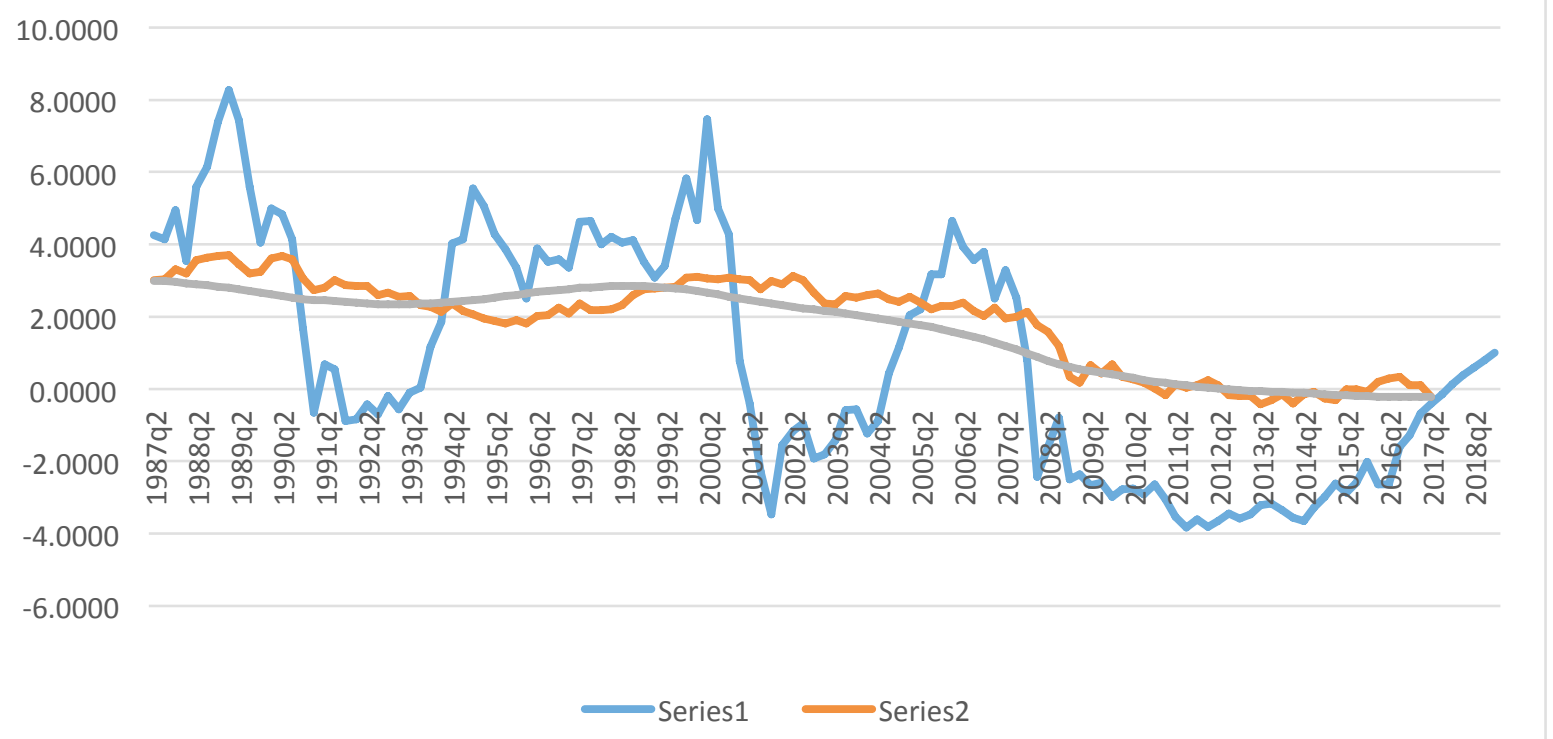


Figure 3: Univariate measures of trend real interest rates (Source: Hamilton, 2015)

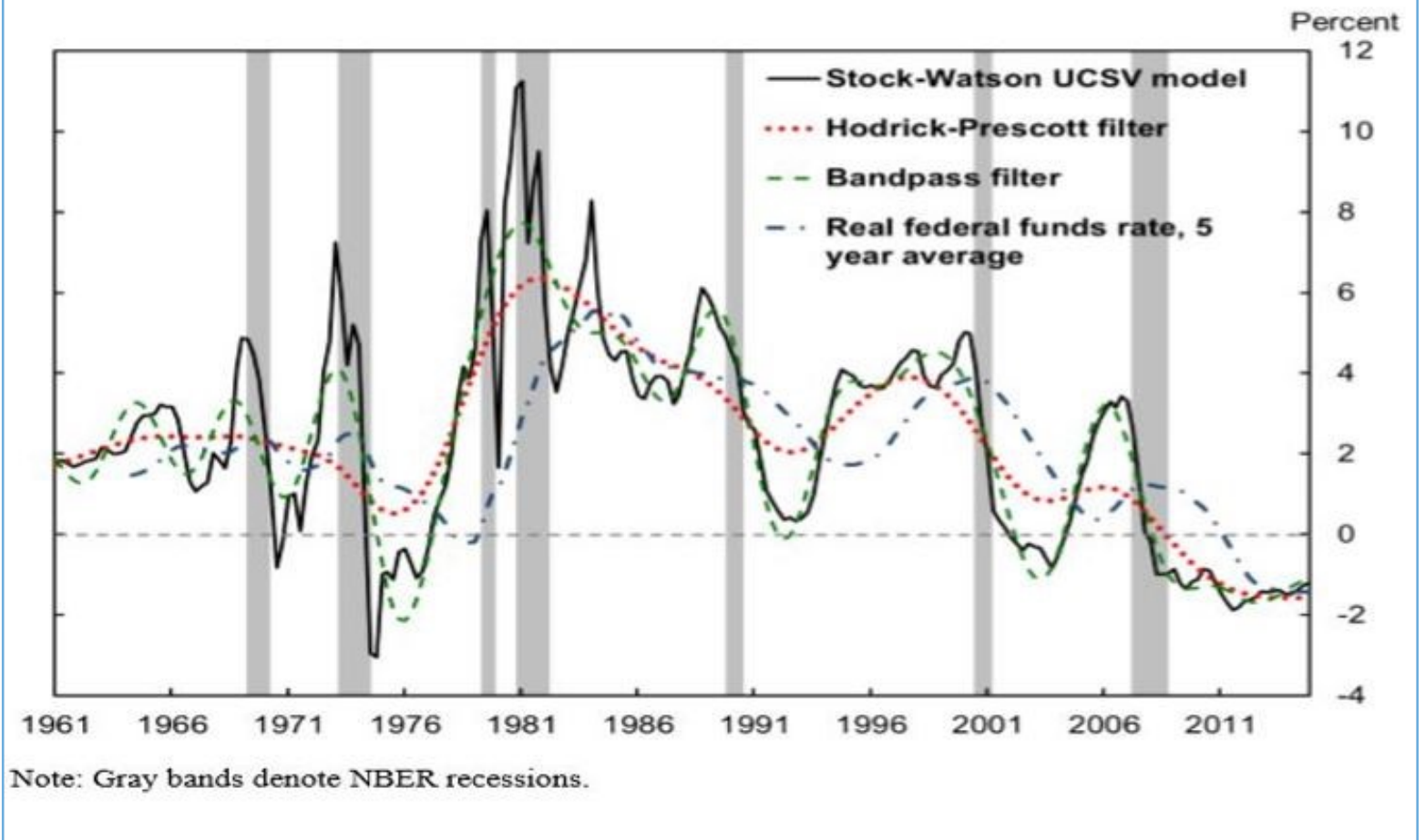

2007) criticized Fed monetary policy after 2010 for being too expansionary - a thesis that Bernanke refuted due to the absence of accelerating inflation. On the contrary, those who referred to a quasi-natural rate of interest and deemed that it fell sharply during the crisis due to low expected productivity and a rising propensity to save (cf. Curdia, 2015; Del Negro, 2015) evaluated the stance of monetary policy as still not expansionary even when bringing the policy rates towards zero. They also usually call nowadays for a rapid rise in these rates forecasting an increasingly positive NRI over the next few years.

As far as Central banks are concerned, they seem to have adopted a more discretionary or practical approach to fixing the interest rates, especially due to the scant reactivity of aggregate demand to their decisions on policy rates. For example, assuming a natural rate of unemployment to be around 5 per cent, ${ }^{39}$ the Federal Reserve progressively lowered its benchmark interest rate in the years 2008-2013 and deemed it higher than the FFR only after 2014. Moreover, due to uncertain economic prospective growth, the Fed subsequently raised interest rates slowly and moderately although they were deemed to be lower than the NRI according to main estimation methods. ${ }^{40}$

39 By using Okun's Law, Fed's monetary rule is usually indicated as $i_{t}=r_{t}^{n}+\pi_{t}+0,5\left(\pi_{t}-2 \%\right)+0,5\left[-2\left(u_{t}-u_{n}\right)\right]$, where $u_{n}$ is the natural rate of unemployment.

40 This recalls Orphanides\&Williams (2002) rule $i_{t}=a_{o} i_{t-1}+\left(1-a_{o}\right)\left[r_{t}^{n}+\pi_{t}\right]+a_{1}\left(\pi_{t}-2 \%\right)+a_{2}\left(u_{t}-\right.$ $\left.u_{n}\right)$. 
This behavior is not surprising when considering the wide dispersion of the estimates of a theoretical variable like the NRI which should have a (unique and) definite value independent of monetary policy. It is a sign that problems arise when finding an empirical counterpart for the NRI, thus raising questions about the use of monetary rules where it appears explicitly as the targeted policy rate. These problems have been highlighted after the 2008 financial crisis when several estimates of the NRI provide negative values of it on average and not only as a possible (short-lived) effect of temporary shocks, as suggested in the framework of NewKeynesian models (cf. Woodford, 2007: 251). ${ }^{41}$ As we will see, the odd idea of technological change and individual time preferences leading to negative normal capital profitability stemmed from an attempt to reconcile what was forecastable according to the prevailing macroeconomic models and the actual experience of market economies.

\section{The unnatural natural rate of interest}

A first conclusion may be drawn from the analysis of the estimates of the NRI: they are statistically uncertain and vary according to the estimation method that is used. However, the limits of the NRI as a benchmark for monetary policy are not only statistical or related to the difficulty in distinguishing the kind and persistency of economic shocks; they pertain also to the theory itself, specifically to model specification and the alleged independence of the average or normal interest rate from monetary policy. We will try now to summarize briefly these problems and offer an alternative view of Central Bank behavior in setting the interest rates.

A first point has been outlined by Taylor \& Weiland (2015) and explains why NRI estimates tend to move pro-cyclically. It refers to how the Kalman filter works and the fact that omitted variables or equations may lead to misinterpreting the trend of another variable as a trend of the NRI. The Kalman filter adjusts the interest rate gap (by changing the NRI) when the output gap differs from that forecasted by the model whereas it adjusts potential output when the inflation rate differs from the forecasted one. Yet, suppose that the output gap is a function of some variable $m$ other than the interest rate gap, or that monetary authorities deviate from the Taylor rule. ${ }^{42}$ In this case, if the actual gap differs from the forecasted one, the change may

\footnotetext{
${ }^{41}$ However, for the short run, this possibility was already advanced by previous macroeconomic models. Cf., for instance, Modigliani (1975).

42 On this possibility cf. for example Taylor (1992), Blinder and Reiss (2005), Hetzel (2015). It has often led to adjusting the values of the parameters and the unobservable variables in order to fit better the data, resulting in a variety of possible monetary policy rules with different policy implications and a loss of their prescriptive role.
} 
arise from a different value of $m$ or a systematic deviation from the monetary rule, rather than from a higher or lower NRI. ${ }^{43}$

A second point concerns the focus of New-Classical and New-Keynesian models on the volatility of output, that is, its variance, on the assumption that the output gap will be closed by market forces. It underrates the fact that the second moment of output is of second-order with respect to its average (cf. Summers, 2014). What is hidden indeed is that potential output may fall during the crisis due to the destruction of productive capacity that stems from a fall in effective demand. This would break down the distinction between short-lived demand shocks on the one hand and supply shocks on the other. ${ }^{44}$ This would complicate any estimate of the NRI, raising questions about its theoretical relevance and a clear distinction between demand and supply factors. As we will see, it also leads to questions about the long-run neutrality of monetary policy. ${ }^{45}$

This brings us to the core of the criticism of the NRI notion and estimates, namely the relations between prices, output and the rate of interest put forward in the New-Keynesian models.

In the first place, output elasticity with respect to interest rates appears low and asymmetric (cf. Goodhart, 1984: 24). The fall in the latter may stimulate public expenditure by lowering the cost of the service of public debt ${ }^{46}$ and may determine an increase in net exports thanks to the depreciation of the exchange rate. However, its effects on consumption and investment are uncertain and vary according to circumstances. ${ }^{47}$ For the greatest part of the population

\footnotetext{
${ }^{43}$ According to Taylor\&Weiland, Laubach's estimates would indeed underrate the value of $m$ and the Fed's deviation from the Taylor rule and the NRI should be left unchanged at its steady state level of 2 per cent. A way to reduce this misspecification of the model may be to introduce demand shifters in the IS curve as did Kiley (2015).

${ }^{44}$ Summers (2014) outlines that in the US the convergence of actual to potential output in recent years also happened thanks to an estimated fall of potential output, so that, while in 2014 the actual output was 10 per cent lower than its pre-crisis level, potential output fell by 5 per cent. In the meantime, even if the unemployment rate moved towards 5 per cent, the employment to population ratio remained below the pre-crisis level. The fall of potential output is seen to stem directly from the fall in capital accumulation and indirectly from its negative effects on total factor productivity and participation rates. Cf. also Ball (2014), Reifschneider, Washen \& Wilcox (2013) and Stockhammer \& Sturns (2012).

${ }^{45}$ Note that in New-Keynesian models only supply factors affect the NRI. The possibility that effective demand has an influence on productive capacity and labor productivity opens an identification problem regarding the nature and effects of frictions and shocks. As stressed by Reifschneider, Washen \& Wilcox (2013: 26), the statistical methods used to distinguish between cycle and trend hide these problems.

${ }^{46}$ However, by itself the payment of a lower amount of interests on public debt may reduce total expenditure according to the propensities to consume of those who receive such interest payments.

${ }^{47}$ What matters for residential and fixed capital investments is of course the long-run interest rate and, as noted by Kaldor (1982), inventories are often financed by long-term capital too. The relation between the (nominal) shortrun policy rate and the (real) long-run interest rate is thus crucial for the transmission of monetary policy. If they diverge for short periods, Central Banks have, however, instruments to influence the long run interest rates.
} 
belonging to the lower percentiles of income and wealth, consumption is driven mostly by past and current income in contrast to what is implied in the Euler equation, and a fall in the interest rates may increase aggregate consumption primarily by shifting income distribution in favor of wages that increases the overall propensity to consume. For the credit unconstrained sections of population, habits and the decrease of income out of financial assets when the interest rate falls may overwhelm or at any rate reduce both the positive wealth effect and that of the lower cost of borrowing (cf. Campbell \& Mankiw, 1989; Hall, 1988, Lawrence, 1991), and phases of debt deleveraging as occurred after the 2008 crisis may have strong negative effects on consumption expenditure.

An analogous uncertainty holds for investments, both on empirical and theoretical grounds. The effect of changes in the interest rate appears to be higher for residential investments and in the energy and transport sectors. Yet, given the desired capital-output ratio, investments in fixed capital are determined mainly by expected changes in aggregate demand, and in particular, by its autonomous components rather than by the interest rates (cf. Chirinko, 1993; Fazzari et al., 1988; Chirinko, Fazzari \& Meyer, 1999). Moreover, the mechanism itself advanced to justify an inverse relation between investments and the rate of interest has been criticized: cost-minimization that may change the capital-output ratio does not necessarily work in the direction of capital deepening when the interest rate falls. ${ }^{48}$

The fact that a fall in the interest rate does not necessarily lead to an increase in aggregate demand means that we cannot interpret a low elasticity of output to the interest rate as a sign that the natural rate of interest has fallen. ${ }^{49}$ Something similar applies to prices. According to New-Keynesian models, there should in fact be a higher inflation rate associated with a lower interest rate. However, the Gibson paradox and its modern restatement in the price puzzle suggest that this may not be the case and that a direct relation between prices and the interest rate may exist. Rather than the market interest rate moving to its natural level as suggested by Wicksell, in a fiat economy it may stem from prices adjusting to the monetary costs of

\footnotetext{
${ }^{48}$ See the brief recall of the results of capital controversy below. Note also that the kind and intensity of technical progress and thus autonomous investments are affected by the course of effective demand (cf. Rosenberg, 1989). With regard to the mechanization of production, it may be stimulated by a fall in the rate of profit, as a reaction to an increasing workers' bargaining strength (cf. Schefold, 1976). This possible "Ricardian effect" must be distinguished, however, from the neoclassical substitution effect and only under specific assumptions leads to an increase in labor productivity.

${ }^{49}$ This is the prevailing interpretation of the recent experience of negative real policy interest rates and income growth rates that are only slightly higher than its estimated trend. As noted by Lubick \& Matthes (2015), distorted estimates of the NRI may arise also from misspecification of the Phillips Curve whose slope may also become negative.
} 
production that include the pure remuneration of capital, namely interest costs (cf. Pivetti, 1991; and Surico, 2008, for his proposal within a New-Keynesian framework). Again, this implies that, if, after a fall in the interest rate, we observe a fall in prices (or a una tantum lower rate of inflation), this does not afford any indication that the NRI should be lower. ${ }^{50}$

However, a more fundamental criticism can be advanced concerning the sheer existence of a natural rate of interest that is determined by "productivity and thrift" and is independent of the monetary policy. ${ }^{51}$ New-Keynesian models restate (cf. Seccareccia, 1998) the loanable funds theory, viewing the market rate of interest as determined by the supply of and demand for credit, and the natural rate by the supply of and demand for savings when output is at its potential level (cf. Robertson 1962: 64-74; 1963). As in Robertson (1962: 23), in the absence of disturbances and rigidities, the real rate of interest would eventually adjust to the value assuring full employment and since profit expectations would govern the demand for credit, the marginal productivity of capital would shape the interest rate.

The loanable funds theory was already criticized by Keynes who questioned the fact that investments adjust to savings through changes in interest rates. Unlike in the Treatise on Money, in the General Theory Keynes argued that savings equalize investments by means of income changes and deemed the notion of the NRI as not useful (cf. Keynes, 1936: 243), viewing in turn the rate of interest as a monetary phenomenon to which capital profitability will adjust. He also specified that credit is not an alternative to savings but the necessary preparation for them (cf. Keynes, 1939), and that until potential output is achieved, investments are financed by the finance process and income changes rather than by any previous saving supply. ${ }^{52}$

Within this analytical framework, Keynes maintained that there is no mechanical tendency to full employment and that unemployment stems from a lack of effective demand rather than any money price rigidity (cf. Keynes, 1936, especially chapter XIX). Nevertheless, the presence in his analysis of traditional elements such as the curve of the marginal efficiency of

\footnotetext{
${ }^{50}$ Sims (1992) stated that the price puzzle disappears when considering oil price shocks. See on this point, however, Barth \& Ramey (2001) and Christiano and others (2005).

${ }^{51}$ We do not consider here the possibility of forced savings or a destruction of productive capacity stemming from interest rates that are different from the NRI. In the neo-Wicksellian literature, these possible channels of adjustment of the NRI to the market interest rates rather than the opposite are usually neglected or have a temporary nature.

${ }^{52}$ In the same vein, a rise in the propensity to save will not increase investments according to Keynes and since credit is not limited by savings, capital accumulation cannot stem from them (cf. Goodhart, 1984).
} 
capital (cf. Garegnani, 1979) has left open the possibility of thinking of a "neutral" interest rate by which investments may equalize savings at full employment whenever fitful and transitory factors average out. Based on these premises, it has also been easy to argue that this "neutral" rate will be that shaped by "productivity and thrift" (cf. Robertson, 1963), ${ }^{53}$ thus restoring the conclusions of the loanable funds theory.

However, for this restatement, the homogeneity of financial capital must be reconciled with the heterogeneity of real capital. In fact, with several capital goods, only their specific rate of returns can be determined unless capital is conceived of as a value magnitude able to change its form. It is for this reason that Wicksell (1934: 204-5), although aware that the value of capital varies with changes in the relative prices, took capital supply as given in the same unit of output or value when determining the (uniform) rate of profits (cf. Garegnani, 1990; and Petri, 2005). ${ }^{54}$

However, the dependence of the value of capital (a composite commodity of different capital goods) on prices and thus on the rate of interest (cf. Sraffa, 1960) makes it impossible to take capital supply as given as a single magnitude when determining relative prices. It also makes it impossible to derive a decreasing supply curve of firm bonds (namely, a decreasing demand curve for investments) with regard to the interest rate which is at the root of the neoclassical mechanism guaranteeing the tendency of actual to potential output (cf. Rogers, 1989). As the capital controversy has shown (cf. Pasinetti, 1966; Garegnani, 1970), unless a single commodity economy is assumed, a surrogate production function cannot be derived due to the phenomena of re-switching and reverse capital deepening. Indeed, something like what is shown in Figure 4 may happen in the saving-investment market: there may be multiple equilibria, a capital-labor ratio that in equilibrium is not necessarily higher for a lower interest rate, and changes in the rate of interest out of the equilibrium that are so strong that they question the validity of the theory (cf. Garegnani, 1990; Fratini, 2007).

\footnotetext{
${ }^{53}$ Even Harrod (1960) accepted Robertson's thesis and his criticism of Keynes's theory of interest that "if [the interest rate] is not expected to become other than it is, there is nothing left to tell us why it is what it is".

${ }^{54}$ Note that Woodford (2003: 167 and 353) maintains that in the short run capital goods should be treated as specific inputs with different real rental rates. Sometime he also refers to an economy with a single good (cf. idem, 41). However, the reference to capital as a value magnitude is implicit when he argues that there will be a tendency of capital to shift towards sectors with higher capital returns and that investment goods are perfect substitutes for savers (cf. Woodford, 2003:166). It is also implicit in the investment functions with adjustment costs of the New-Keynesian models or when it is argued that firms borrow at a rate equal to the value of the marginal product of capital. On the other hand, for a critique of an analysis of monetary phenomena and the relation between the money rate of interest and the natural rate of interest using DSGE models where all spot and forward prices are set at the initial date, see Rogers (2018).
} 
It should also be noted that, even if the results of capital controversy did not question the neoclassical theoretical approach, the multiplicity of equilibria by itself questions the idea of the NRI as a benchmark for monetary policy. ${ }^{55}$ Central banks, in fact, would not only be uncertain over the estimates of the NRI. Even if they knew the possible equilibria exactly, they would also have to select the one towards which to move the policy interest rate based on subjective ordering of these equilibria. ${ }^{56}$

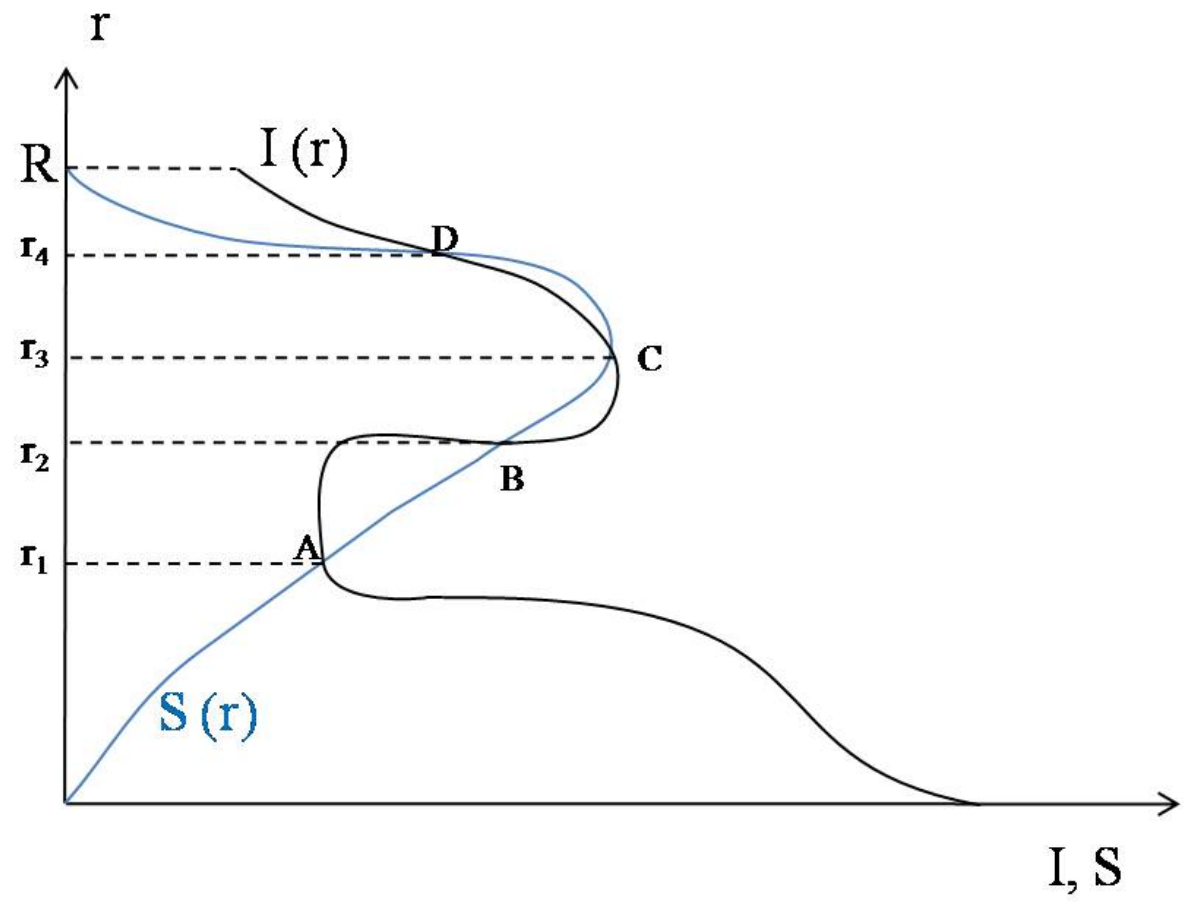

\begin{abstract}
Figure 4: Multiple equilibria in the savings-investiment market. The saving function follows the hypothesis that only the young generation saves out of wages (see Fratini 2007).
\end{abstract}

\title{
5. The monetary rate of interest and Central Banks policies
}

Where does the above criticism to the notion and estimates of the NRI take us? First of all, putting aside the loanable funds theory means that due prominence can be given to Keynes's (1936: 203) idea that the rate of interest is a highly conventional phenomenon. Second, it

\footnotetext{
${ }^{55}$ As Sonneschein-Mantel-Debreu theorem shows, also in the case of the neo-Walrasian versions of general equilibrium theory, where prices are distinguished by date of delivery, the existence, but not unicity and stability, of the equilibrium is proven, unless restrictive assumptions are introduced (cf. Kirman, 1989). Moreover, price indeterminacy may arise in a sequential economy for a class of linear models when the number of consumption goods is lower than the number of inputs (cf. Mandler, 1995; and Fratini \& Levrero, 2011). While challenging the significance of the theory (cf. Petri, 2004), the neo-Walrasian abandonment of the notion of long-run equilibrium would thus not solve the issues mentioned above concerning the implementation of monetary policies.

${ }^{56}$ This point is different from the possibility of global indeterminacy of the price level outlined by Benhabib and others (2001), which would imply that monetary authorities ought to influence price expectations in order to achieve local determinacy.
} 
opens the way for levels of the rates of interest that are shaped by monetary authorities to affect income distribution, as suggested by Sraffa (1960: §44) in Production of Commodities by Means of Commodities (cf. Dobb, 1973; Garegnani, 1979; Panico, 1988; Pivetti, 1991), and this possibility casts a different light on the purposes and channels of transmission of the monetary policies. Of course, monetary policy is not advanced in a vacuum but takes into account the course of money wages and, more generally, the economic and financial conditions of the country involved. Yet, the benchmark rate to which monetary authorities anchor their day-to-day decisions does not appear to reflect "fundamental forces" acting independently of monetary factors, and therefore those decisions cannot be conceived simply as a technical device used to find out the "true" natural interest rate.

To grasp how the monetary authorities can influence income distribution, let us suppose that wages are above the subsistence level. Following Ricardo, let us consider the two components of the rate of profits, namely the normal profits of enterprise rewarding the "risk and trouble" to use capital productively and the rate of interest which is the pure remuneration of capital, usually measured by the average rate of interest on long-term riskless bonds. If the latter is a monetary phenomenon ${ }^{57}$ and the normal profit of enterprise is taken as given, it is the rate of profits that has to adjust to the rate of interest. Given the money wages and the methods of production, in a fiat money economy this adjustment will pass through a change in the ratio of money prices to money wages in order to cover the normal monetary costs of production (cf. Pivetti, 1991). ${ }^{58}$ This implies that monetary policy may be viewed as one of the elements shaping income distribution together with the normal profits of enterprise and the course of money wages, with results depending on the relative bargaining strength of the parties involved. It also leads to a cost explanation of inflation that accelerates whenever the real rate

\footnotetext{
${ }^{57}$ Note that Ricardo did not view the rate of interest as determined by the rate at which the bank system lends, but by the employment of capital (cf. Ricardo, 1951-73, I: 363), namely as a real phenomenon although determined by forces that are different from "productivity and thrift." Within the surplus approach to value and distribution, it was Marx (1961-63) in the Volume III of Das Kapital who recognised the monetary nature of the rate of interest, maintaining that only pedantry would see it as stemming from real forces and considering it as determined by the relative bargaining powers of borrowers and lenders in the financial circulation. However, since Marx treated the rate of profit as determined by the same real forces as those advanced by Ricardo, he conceived the conflict between financial and industrial capital as only dividing the rate of profits between the rate of interest and the normal profits of enterprise.

${ }^{58}$ Interest payments on short term lending to firms may also have this effect on prices (cf. Panico, 1988; and Barth \& Ramey, 1991). The way in which the rate of profits adapts to the rate of interest differs thus from that considered by Keynes, namely variations in capital demand and supply prices when investments change due to a gap between the marginal efficiency of capital and the rate of interest. The fact that commodity prices and thus firm revenues vary together with the latter can help to explain why investments are not sensitive to the rate of interest.
} 
of interest targeted by the monetary authorities conflicts with the real wage rate pursued by workers in wage bargaining (cf. Levrero, 2013 and 2018). ${ }^{59}$

The influence of monetary policy on income distribution is widely recognized, although it is conceived to act by means of a variety of channels and within different views regarding the forces that shape the rate of profits (cf. for instance Eichner, 1986: 860; Rogers, 1989; Smithin, 1996: 93 and 97; Lavoie and Seccareccia, 2004; Wray, 2007: 120). It rests on the assumption that monetary authorities may on average fix both the short-term interest rates and the course of long-term rates. Central Banks act in this respect not only by shaping expectations on the future short rates but also by modifying net supplies of safe and risky assets through open market operations, as well as by varying the assets admitted as collateral and their haircuts when financing the bank system, thus affecting liquidity and risk premia.

A spectrum of constraints and objectives is behind the interest rates pursued by the monetary authorities. Their relative weight may differ according to the relations that historically Central Banks have had with the financial and government sectors as well as the bargaining power achieved by the workers (cf. e.g. Mitchell and Erikson, 2005). They may also be in conflict with each other.

Typically, monetary authorities aim to stabilize prices and defend the external value of the currency while assuring a "conventional" or normal rate of interest. They operate in this regard as the manager of a bank club (cf. Goodhart, 1984: 176) defending the lenders against inflation and strengthening the international position of the home financial sector. It is this aspect that Keynes (1936) referred to when stressing that the interests of the City of London led to an interest rate that was on average higher than that able to achieve full employment.

To assure on average the benchmark real rate of interest, Central Banks usually react to any increase in money wages that may lead to an inflation rate that is higher than the targeted one, and thus to a change in income distribution (cf. for instance Dickens, 2016; Dullien, 2004), by raising the nominal rates of interest. However, they may be pushed to accept lower real

\footnotetext{
${ }^{59}$ While wage bargaining acts on money wages, monetary policies fix the nominal interest rates. If the latter remain unchanged, a continuous increase in money wages will lead to an increase in real wages, which will be higher the lower the share of wages in the gross product. This does not happen if the monetary authorities react by increasing the nominal rate of interest in order to maintain a desired real interest rate (cf, Levrero, 2013). The consequent accelerating inflation will come to an end whenever this rate is lowered by the monetary authorities or increasing prices and nominal interest rates lower workers' bargaining power by rising the rate of unemployment or reducing their degree of organisation. It may also end if a rise in labor productivity or improvements in the terms of trade allow workers' wage requests to be reconciled with the monetary policy benchmark rate.
} 
interest rates when the increasing bargaining power of workers would otherwise determine accelerating cost inflation. Considerations on the effects of inflation on the external position of the country and on fixed incomes certainly play a role in this regard.

As stressed by the Radcliffe Report, a shift to a lower gear regime may also stem from the need to minimize the cost of the service of public debt and assure financial stability. The pressure in this direction will be greater the greater the weight assigned by the monetary authorities to the aim of full employment, which in turn reflects the relations between capital and labor in a given country and period. Moreover, it will be greater if financial stability requires monetary authorities acting as the lender of last resort ${ }^{60}$ to do it by reducing borrowing costs in order to refinance an over-indebted economy and sustain asset prices. ${ }^{61}$

A reaction function similar to the Taylor rule is thus certainly at work in Central Banks (cf. Moore, 1988; Rochon \& Setterfield, 2007; Fontana\& Palacio, 2002), but with significant differences from the rule considered in the New-Keynesian models. ${ }^{62}$ First, as stressed above, the benchmark rate is not set by real forces as in the case of the NRI notion, although Central Banks do not act in a vacuum. Second, the variation of the rate of interest in reaction to discrepancies between the actual and target inflation rates has uncertain effects on the rate of inflation. In particular, the elasticity of aggregate demand with respect to the interest rate is asymmetric and it may take time for the monetary policies to have an effect on prices. ${ }^{63}$ While in fact a substantial rise in the interest rate may depress the economy, the effect of its fall is uncertain since "you can lead a horse to water but it may not drink." with fiscal policies is required (and is often performed) in order to achieve a target rate of inflation. Finally, the relation between prices and employment is also different from that advanced in New Keynesian models. For a range of capacity utilization, there may be constant

\footnotetext{
${ }^{60}$ Indeed, especially since the 1990s, Central Banks have became lenders of first resort in order to avoid credit crunches (cf. De Cecco, 1999).

${ }^{61}$ As after the collapse of the tech bubble at the beginning of 2000 , or after the 2008 crisis, low interest rates are often implemented to sustain consumption and thus capital accumulation. As in after the Second World War (cf. Kaldor, 1982), this "low gear regime" usually leads to increasing pressure from the bank sector and rentiers for a rise in interest rates, especially whenever it has been associated with lowering profit margins of the bank sector. In these circumstances, Central Banks act to guarantee the reproducibility of the economy over time and do not necessarily pander to the requests of the financial sector, while assuring it the liquidity it needs.

${ }^{62}$ Albeit only as the result of the unpredictability of the demand function for money, these models share the fact that money is endogenous and monetary authorities fix short-term interest rates.

${ }^{63}$ The uncertainty also stems from the fact that prima facie an increase in the interest rate leads to an increase in prices. A lower rate of inflation depends thus on its effect on the course of money wages.

${ }^{64}$ Note also that drastic changes in interest rates ought to be avoided due to the negative effect on financial stability. Moreover, as in recent years, credit expansion may not be accompanied by an increase in aggregate demand.
} 
cost and thus no pressure on the price level when employment changes. ${ }^{65}$ Moreover, when taking into account the effect of this change on the strength of workers in wage bargaining, the influence of labor market conditions on the course of money wages may be advanced both in the short and long run, together with that of institutional factors that shift the relation between those variables over time. This implies that, in order to achieve a targeted inflation rate, Central Banks may avoid a wage-price spiral by accepting a real interest rate that is consistent with a fairer income distribution ${ }^{66}$ and a higher amount of employment for which inflation does not accelerate. The "cold turkey" alternative with a strong increase in the nominal interest rates cannot but pass through an increase in the unemployment rate also due to redistributive effects in favor of creditors (cf. Lavoie and Seccareccia, 2016).

\section{Some final remarks}

Summing up, estimates of the NRI are misleading both on empirical and theoretical grounds, and monetary policy is not neutral, primarily because it may influence the division of the surplus product among different classes and social groups. Quite paradoxically, however, the tricky nature of those estimates, with their consequent downward revision during the crisis due to their sensitivity to current economic conditions, has helped and has been used by Central Banks to pursue a regime of low interest rates that was required by the macroeconomic situation of industrialized countries after the 2008 crisis. The cost of doing this has been to hide the asymmetric effects and delay in the transmission of monetary policy since the scant reactivity of output to a fall in interest rates has been explained precisely by an alleged fall in the natural rate of profits - even to negative values - due to reaching the zero lower bound for policy nominal interest rates. ${ }^{67}$

The fall in the natural rate of interest has been ascribed primarily to a fall in the population growth rate and technical progress, as well as to an increase in the propensity to save fuelled

\footnotetext{
${ }^{65}$ Lavoie (1998) calls it the Post-Keynesian Phillips Curve and expresses it as $\pi=a\left(k-k_{m}\right)+b\left(k-k_{f}\right)+\pi_{n}$, where $k$ indicates the degree of capacity utilisation, and $\pi_{n}$ the "normal" inflation rate within a certain output range. We have $a=0$ for $k>k_{m}$ and $a>0$ for $\mathrm{k}<k_{m}$, with $b=0$ for $k<k_{f}$ and $b>0$ for $\mathrm{k}>k_{f}$. So, for $k_{m}<k<k_{f}, \pi$ is constant.

${ }^{66}$ Different normative proposals have been advanced in this regard from the Kansas City rule of an interest rate leading to the euthanasia of rentier (Wray, 2007; Forstater \& Mosler, 2004), to the Smithin rule (2004: 686) of a real rate of around 2 per cent. Sawyer advances the proposal of a "fiscal real rate," namely a rate lower than the growth rate of the economy in order to leave space for expansionary fiscal policies without increasing public debt, whereas Lavoie\& Seccareccia (1999) propose a nominal "fair rate" equal to labor productivity growth rate plus the inflation rate.

${ }^{67}$ In more recent models, in order to explain this scant reactivity, frictions in the credit markets affecting the NRI itself have been introduced to the DSGE models. Cf. for instance Vines and Wills (2018) and Krustev (2018).
} 
by greater uncertainty over the future (cf. Baker, de Long and Krugman, 2005; Baldwin and Teulings, 2014). ${ }^{68}$ Yet, the low growth rates in the main industrialized countries appear to have been the result mainly of a lack of effective demand, in turn reflecting increasing inequality, a shift of income distribution to profits (cf. Summers, 2014; Barba \& Pivetti, 2011; Stirati, 2013), and, especially in Europe, restrictive or insufficient expansionary fiscal policies. ${ }^{69}$ Moreover, it seems difficult to think of a fall in the normal rate of profits when looking at the course of income distribution. ${ }^{70}$ Setting aside the pro-cyclical change in both the share of profits out of income and capacity utilization, in the main industrialized countries there has been a decreasing trend in the wage share, especially when calculated net of management wages. Due to the uncertain trend of the capital-output ratio (that, however, does not seem to have increased), the (ex-ante) normal rate of profit, albeit not directly measurable, has thus probably risen (or at any rate, not fallen) in the main industrialized countries.

This also seems to be confirmed by looking at its components, namely the real interest rate or pure remuneration of capital and the normal profits of enterprise. While on average the longterm interest rate on safe bonds has fallen (but less in real than in nominal terms due to the fall in the inflation rate), the normal profits of enterprise have risen, due to increasing liquidity and risk premiums determined by market deregulation, an increase in management wages, and a rise in monopoly rents. For instance, if the interest spread between safe and risky assets was constant until 2000, risk premiums rose after the collapse of tech bubble and again after the 2007-2008 crisis, and on average passed from 6 per cent from 2000-2008 to 9 per cent between 2008 and 2015 (cf. Caballero and Fahr, 2014; King and Low, 2014). ${ }^{71}$

\footnotetext{
${ }^{68}$ As stated in Section 2, in neoclassical growth models the rate of profits is usually expressed by $r=q / \sigma+\beta+\sigma n$, where $q$ is labor augmenting technical progress, $\sigma$ the inter-temporal elasticity of substitution, $\beta$ the household rate of preference and $n$ the rate of growth of population. In the debate on secular stagnation, other factors outlined to explain the fall in the rate of profits are the deleveraging process after 2007 crisis (cf. Eggerstroon and Mehotra, 2014; Rogoff, 2015) and the increasing integration of China and other developing countries in the international financial markets (cf. Bean, Broda and others, 2015). However, it has been estimated that their effect will decrease due to an aging population and the enlargement of the domestic market in these countries. Moreover, it is difficult to ascertain the intensity and kind of innovations.

${ }^{69}$ A negative effect on investments also stemmed from the falling trend in capital goods prices and the kind of innovations, setting a tendency to fall of the capital-output ratio. The low capital accumulation has had in turn negative effects on productivity growth.

${ }^{70}$ It is even more difficult to imagine a negative ex ante real interest rate. If some own rates of interest become negative due to changes in relative prices over time, as Fisher stated (1930: 82), a zero or negative real interest rate is "practically impossible." Moreover, only "in times of revolution" some capitalists may prefer "to forego the chance of all interest and merely hoard their capital in money form, even paying for storage charges (.....)" (Fisher, 1930: 245). Cf. also Moore (1988: 262) on the effect on the present value of real assets of a discount rate passing through zero.

${ }^{71}$ One of the aims of the Central Banks's quantitative easing programs had been precisely that of reducing these premiums, the spread between safe and risky assets having reached 14 per cent in the years 2008-2010.
} 
If the expected rate of profit does not seem to have fallen, and if, when looking at the condition of the labor market, there still appears to be room for increasing the levels of employment, the present increasing pressure to raise the (free-risk) real interest rates that finds support also from the current shift to estimates forecasting rising natural rates may have negative effects on economic growth. Rather than attention being focused on tapering from quantitative easing, ${ }^{72}$ a monetary policy for growth (Harrod, 1940) should be directed towards greater financial market regulations that are able to reduce the risk of speculation, as well as towards instruments that guarantee sufficient net yields to household savings, especially pension funds. A regime based on low interest rates, fiscal deductions on some financial investments, and measures reducing the degree of concentration in financial markets and international capital mobility, may be the way to favor economic growth and a fairer income distribution.

\footnotetext{
${ }^{72}$ Note that there is nothing unconventional in quantitative easing. As Keynes (1936: 206) stressed "perhaps a complex offer by the Central bank to buy and sell at stated prices gilt-edged bonds of all maturities in place of the single bank rate for short-term bills, is the most practical improvement which can be made in the technique of monetary management".
} 


\section{References}

Andres, J., Lopez-Salido, J. D. and Nelson, E. (2004), 'Money and the Natural Rate of Interest: Structural Estimates for the UK, the US and the Euro Area', Discussion Paper No. 4337, Centre for Economic Policy Research.

Baker D., Bradford de Long J., Krugman P. R. (2005), Assets Returns and Economic Growth, Brookings Papers on Economic Activity, 2005, vol. 36, issue 1, 289-330.

Baldwin R. and Teulings C. (eds.) (2014), Secular Stagnation: Facts, Causes and Cures, A VoxEu.org Book, CEPR Press.

Ball L. (2014), Long term damage from the Great Recession in OECD countries, European Journal of Economics and Economic Policies, 11(2), 149-160.

Bank of England (2013), The Bank of England's forecasting platform: Compass, Maps, Ease and the suite of models, Working Paper no. 471, May.

Barba A. and Pivetti M. (2009), Rising household debt: its causes and macroeconomic implications - a long period analysis, Cambridge Journal of Economics, 33: 113-37.

Barsky, R., Justiniano A., and Melosi L. (2014), The Natural Rate and its Usefulness for Monetary Policy Making”, American Economic Review Papers and Proceedings, 104(7), pp. 37 - 43.

Barth M. and Ramey V. (2001), The cost channel of monetary transmission, in Bernanke B.S., Rogoff K. (eds.), NBER Macroeconomics Annual, vol. 16, The Mit Press, Cambridge, pp. 199-239.

Bean C, Broda C., Ito T. and Kroszner R. (2015), Low for Long? Causes and Consequences of Persistently Low Interest Rates, ICBM International Center, Geneve, CEPR Press.

Benati L and Vitali G. (2007), Joint Estimation of the Natural Rate of Interest, the Natural Rate of Unemployment, Expected Inflation, and Output Potential, Working Papers Series NO 797, August, European Central Bank.

Benigno P. and Woodford M. (2005), Inflation Stabilization and Welfare:The Case of a Distorted Steady State, Journal of the European Economic Association 3, no. 6, 1185-1236

Benhabib, J., Schmitt-Grohe' S. and Uribe M, (2001), Monetary Policy and Multiple Equilibria, American Economic Review, 91:167-86.

Bernanke, B.S. and Blinder A.S.(1992), The Federal Funds Rate and the Channels of Monetary Transmission, American Economic Review, September, 901-21.

Bernanke B. and Mihov I. (1998), Measuring monetary policy, Quarterly Journal of Economics, 113, 869-902.

Bernanke, B.S., Laubach T, Mishkin, F.S. and Posen, A.S (1999), Inflation Targeting: Lessons from the International Experience, Princeton: Princeton University Press, 1999.

Blanchard O., D. Furceri, and Pescatori A., (2014), A Prolonged Period of Low Real Interest Rates?, in Secular Stagnation: Facts, Causes and Cures, edited by Teulings, C. and Baldwin, R., VoxEu, August.

Blinder, A. (1998), Central banking in theory and practice, Lionel Robbins Lectures: MIT Press. 
Blinder, A, and Reiss R. (2005), Understanding the Greenspan Standard, Proceedings - Economic Policy Symposium - Jackson Hole, issue August, 11-96.

Bomfin A.N. (2001), Measuring Equilibrium Real Interest Rates: What can we learn from yields on indexed bonds? Finance and Economic Discussion Series 2001-53, Federal Reserve Board.

Bosworth, B. P. (2014), Interest Rates and Economic Growth: Are They Related?, Brookings Institution Working paper.

Bullard, J. and Mitra K. (2002), Learning about Monetary Policy Rules, Journal of Monetary Economics, 49, no. 6, 1005-1129.

Caballero R.J. and Fahri E. (2014), On the role of safe assets shortages in secular stagnation, in Baldwin R. and Teulings C. (eds.) (2014), Secular Stagnation: Facts, Causes and Cures, A VoxEu.org Book, CEPR Press.

Campbell, J. Y. and Mankiw N.G. (1989), Consumption, Income and Interest Rates: Reinterpreting the Time Series Evidence, in NBER Macroeconomics Annual 1989, Volume 4, pp. 185-246, National Bureau of Economic Research.

Campbell, J., \& Cochrane, J. H. (1998). By force of habit: A consumption-based explanation of aggregate stock market behavior, Journal of Political Economy, 107, 205-251.

Carroll, C. D. and Summers L.H. (1991), Consumption Growth Parallels Income Growth: Some New Evidence, in Bernheim B.D. and Shoven J.B. (eds) National Saving and Economic Performance, Chicago: Chicago University Press, pp. 305-348.

Castelnuovo E. and Surico P. (2006), The price puzzle: fact or artifact, Bank of England Working Paper no.288.

Chirinko R.S. (1993), Business Fixed Investment Spending: A critical survey of modelling strategies, empirical results and policy implications, Journal of Economic Literature, 31, 1875-1911.

Chirinko, R.S., Fazzari S. M. and Meyer A. P. (1999) How Responsive Is Business Capital Formation To Its User Cost?: An Exploration With Micro Data, Journal of Public Economics 74 (October), 53-80.

Christiano, L.J., Eichenbaum M.,and Evans C.L. (2005), Nominal Rigidities and the Dynamic Effects of a Shock to Monetary Policy, Journal of Political Economy 113, no. 1, 1-45.

Chou N.T., Izyumov A. and Vahaly J. (2016), Rates of return on capital across the world: are they converging? Cambridge Journal of Economics, 40, 1149-1166.

Clarida R.J., Galì J. and Gertler M, (1999), The scicnce of monetary policy: a new Keynesian perspective, The Journal of Economic Literature, 37(4) 1661-1707.

Clark T.E. and Kozicki S.(2005), Estimating Equilibrium Real Interest Rates in Real Time, North American Journal of Economics and Finance, 16 (3), 395-413.

Cour-Thimann P., Pilegaard R., Stracca L. (2006), The output gap and the real interest rate gap in the euro area, 1960-2003, Journal of Policy Modeling 28, 775-790.

Crespo Cuaresma, J., Gnan, E. and Ritzberger-Gru“nwald, D. ( 2004), Searching for the natural rate of interest: a euro area perspective, Empirica, vol. 31, 185-204. 
Curdia, V. (2015), Why So Slow? A Gradual Return for Interest Rates, Federal Reserve Bank of San Francisco Economic Letter, 2015-32, October 13, 2015.

Curdia, V., Ferrero, A., Ng, G. and Tambalotti, A. (2015), Has U.S. Monetary Policy Tracked the Efficient Interest Rate?, Journal of Monetary Economics, 70, 72-83.

Del Negro M., Giannoni M.P. and Schorfheide F. (2015), Inflation in the Great Recession and New Keynesian Models, American Economic Review: Macroeconomics, 7, 1, 168-96.

Dickens E. (2016), The Political Economy of US Monetary Policy: How the Federal Reserve Gained Control and Uses It, Routledge, New York.

Dullien S.(2004), The Interaction of Monetary Policy and Wage Bargaining in the European Monetary Union. Lessons from the Endogeneous Money Approach, Palgrave Macmillan, Basingstoke.

Dobb M. (1973), Theories of Value and Distribution since Adam Smith. Ideology and Economic Theory, Cambridge, Cambridge University Press.

Edge, R. M., Kiley M.T. and Laforte J.P. (2008), Natural rate measures in an estimated DSGE model of the US economy, Journal of Economic Dynamics and Control, 32, no. 8, 2512-2535.

Eggerstoon G.B. and Mehotra N.(2014), A model of secular stagnation, in Baldwin R. and Teulings C. (eds.) (2014), Secular Stagnation: Facts, Causes and Cures, A VoxEu.org Book, CEPR Press.

Eichner, A. S. (1986). Toward a New Economics: Essays in Post-Keynesian and Institutionalist Theory, London: Macmillan.

Engen, E., Laubach, T. and Reifschneider, D. (2015). The Macroeconomic Effects of the Federal Reserve's Unconventional Monetary Policies, Finance and Economic Discussion Series 005.

European Central Bank (2004), The Natural Real Interest Rate in the Euro Area, ECB Monthly Bulletin, May.

Fazzari, S., Glenn H.R., and Petersen B. (1988), Financing constraints and corporate investment, Brookings Papers on Economic Activity,1, 141-195.

Fontana G. and Palacio-Vera A. (2002), Monetary Policy Rules: what are we learning? Journal of Post-Keynesian Economics, 24, 547.

Fisher I. (1930), The Theory of Interest, New York, Macmillan.

Fiorentini, G., Galesi A., Perez-Quiros G. and Sentana E. (2018), The rise and fall of the natural interest rate, Discussion Paper DP13042, Centre for Economic Policy Research.

Forstater M. and Mosler W.B. (2004), The natural rate of interest is zero, Center for Full Employment and Price Stability, Working Paper No. 37.

Fratini S. (2007), Reswitching of Techniques in an Intertemporal Equilibrium Model with Overlapping Generation, Contributions to Political Economy, 26(1) 43-59.

Fratini S, M. and Levrero E.S. (2011), Sraffian Indeterminacy: a critical discussion, Cambridge Journal of Economics, 35, 6, 1127-1150.

Gali J. (2015), Monetary Policy, Inflation, and the Business Cycle: An Introduction to the New Keynesian Framework and Its Applications, Second Edition. Princeton University Press. 
Garegnani P. (1970), Heterogeneous Capital, the Production Function and the Theory of Distribution, Review of Economic Studies, 37: 407-36.

Garegnani P. (1978-79), Notes on Consumption, Investment and Effective Demand, I-II, Cambridge Journal of Economics, 2(4) and 3(1),

Garegnani P. (1990) Quantity of Capital, in Eatwell J., Milgate M. and Newman P. (eds.), Capital Theory, London, Macmillan.

Garnier, J. and Wilhelmsen, B. R. (2005), The Natural Real Interest Rate and the Output Gap in the Euro Area-A Joint Estimation', The Ecb Working Paper No. 546, European Central Bank.

Giammarioli, N. and Valla, N. (2003), The Natural Real Rate of Interest in the Euro Area, ECB Working Paper No. 233, European Central Bank.

Giammarioli, N. and Valla, N. (2004), The natural real interest rate and monetary policy: a review, Journal of Policy Modeling, vol. 26, 641-60.

Goodhart, C. (1975), Money, Information and Uncertainty, London, Macmillan.

Goodhart, C. (1984), Monetary Theory and Practice: the UK Experience, London, Macmillan.

Gordon R.J. (2014), The demise of U.S. economic growth: restatement, rebuttal and reflections, Working Paper 19895 http://www.nber.org/papers/w19895, NBER.

Greenspan A. (1993), Testimony on 1993 Monetary Policy Objectives to the US Senate, July 20.

Hayek F.A. (1935), Prices and Production, 2nd edition, Routledge and Kegan Paul.

Hayek, F.A., ([1930] 1933), Monetary Theory and the Trade Cycle, London, London School of Economics and Political Sciences.

Hall, R. E.(1988), Intertemporal Substitution in Consumption, Journal of Political Economy, 96(2), 339-357.

Hamilton, J, Harris, E., Hatzius, J. and West, K. (2015), The Equilibrium Real Funds Rate: Past, Present and Future, Working Paper, San Diego, University of California at San Diego, March.

Harrod R. (1960), Money, Macmillan and Co Ltd.

Harvey A.C. (1989), Forecasting Structural Time Series Models and Kalman Filter, Cambridge, Cambridge University Press.

Hetzel, R.L. (2015), What is the Monetary Standard?, Federal Reserve Bank of Richmond Working Paper no 15-16, December.

Holston, K., Laubach T.and Williams J.C. (2016), Measuring the natural rate of interest: international trends and determinants, Federal Reserve Bank of San Francisco, Working Paper 2016-11. http://www.frbsf.org/economic-research/publications/workingpapers/wp2016-11.pdf

Holston, K., Laubach T. and Williams J.C. (2017), Supplement: real time estimates, http://www.frbsf.org/economic-research/economists/john-williams/

Jorgenson D.V. (1963), Capital theory and investment behavior, American Economic Review, 53(2), $247-59$. 
Jorgenson D.V. (1967), The theory of investment behaviour, in R. Ferber (ed,), Determinants of Investment behavior, NBER, pp. 129-175.

Judd, J. P. and G. D. Rudebusch (1998). Taylor rule and the Fed: 1970-1997, Federal Reserve Bank of San Francisco Economic Review 3-16, 3.

Justiniano, A. and Primiceri G.E. (2010), Measuring the Equilibrium Real Interest Rate, Federal Reserve Bank of Chicago Economic Perspectives 34(1): 14-27.

Kaldor N. (1982), The Scourge of Monetarism, Oxford, Oxford University Press.

Keynes, J. M. (1936), The General Theory of Employment, Interest and Money, MacMillan and Co., London.

Keynes, J.M. (1939), The Process of Capital Formation, The Economic Journal, 49: 569-574.

Kiley M.T. (2015), What can the data tell us about the equilibrium real interest rate? Finance and Economics Discussion Series 2015-077. Washington: Board of Governors of the Federal Reserve System, http://dx.doi.org/10.17016/FEDS.2015.077

King M. and Low D. (2004), Measuring the "world" real interest rate, Working Paper 19887 http://www.nber.org/papers/w19887, NBER.

Kirman A. (1989), The intrinsic limit of modern economic theory: the emperor has no clothes, The Economic Journal, 99, n. 395, 126-139.

Krippner, L. (2013), Measuring the Stance of Monetary Policy in ZLB Environments, Economics Letters 118.

Krustev, G. (2018), The natural rate of interest and the financial cycle, ECB Working Paper Series, no 2168.

Lam, J. P. and Tkacz, G. (2004), Estimating policy-neutral interest rates for Canada using a dynamic stochastic general equilibrium framework, Swiss Journal of Economics and Statistics, vol. 140, 89-126.

Laubach T. and Williams J.C. (2001), Measuring the natural rate of interest, Board of Governors of the Federal Reserve System, November.

Laubach, T. and Williams, J. C. (2003), Measuring the natural rate of interest, The Review of Economics and Statistics, vol. 85, 1063-70.

Laubach, T. and Williams J.C. (2015), Measuring the Natural Rate of Interest Redux, Federal Reserve Bank of San Francisco Working Paper 2015-16. http://www.frbsf.org/economicresearch/publications/working-papers/wp2015-16.pdf

Lavoie, M. (2014) Post-Keynesian Economics: New Foundations, New York, Edward Elgar.

Lavoie, M., and Seccareccia, M. (1999), Interest Rate: Fair, in P. O'Hara (ed.), Encyclopedia of Political Economy, vol. 1, London: Routledge, 1999, pp. 543-545.

Lavoie, M. and Seccareccia M. (2004), Long term interest rates, liquidity preference and the limits of Central Banking, in Lavoie M. and Seccareccia M. (eds.), Central Banking in the Modern World, Edward Elgar, Celthenam, UK.

Lavoie, M. and Seccareccia M. (2016), Income Distribution, Rentiers, and Their Role in a Capitalist Economy, International Journal of Political Economy, 45:3, 200-223. 
Lawrance, E. C. (1991), Poverty and the Rate of Time Preference: Evidence from Panel Data, Journal of Political Economy, 99 (1), 54-77.

Levin A., Wieland V. and Williams J.C. (2001), The performance of forecast-based monetary policy rules under model uncertainty, FEDS Working Paper 2001-39, The Federal Reserve Board.

Levrero E.S. (2013), Marx's theory of wages and the revival of the surplus approach, in E.S. Levrero, A. Palumbo and A. Stirati (eds), Sraffa and the Reconstruction of Economic Theory: volume one. Theories of Value and Distribution, London, Palgrave Macmillan.

Levrero E.S. (2018), The Taylor Rule and Its Aftermath: Critical Elements for an Interpretation along Classical-Keynesian lines, Centro Sraffa Summer School, Rome, July.

Lewis, K.F., Vasquez-Grande F. (2017), Measuring the natural rate: alternative specifications, Feds Working Paper no 2017-059.

Lubick T.A. and Matthes C. (2015), Calculating the natural rate of interest: A comparison of two alternative approaches, Economic Brief, 15-10, Federal Reserve Bank of Richmond.

Mandler M. (1995), Sequential indeterminacy in production economies, Journal of Economic Theory, 66: 406-36.

Marx K. (11961-1963) [1867-94], Capital. A Critique of Political Economy, Vols I-III, Moscow, Foreign Languages Publishing House.

Manrique M. and Marques J.M. (2004), An empirical approximation of the natural rate of interest and potential growth, Banco de Espana, Documentos de Trabajo n. 0416.

Mésonnier, J. S. and Renne, J. P. (2006), A time-varying natural rate of interest for the Euro area, European Economic Review, doi: 10.1016/j.eurocorev.2006.11.006

Modigliani F. (1975), The monetary mechanism and its interaction with real phenomena. In The State Of Monetary Economics (pp. 79-107). NBER.

Moore, B. (1988), Horizontalists and Verticalists: The Macroeconomics of Credit-Money, Cambridge: Cambridge University Press, 1988.

Neiss K.S. and Nelson E. (2003), The real interest rate gap as an inflation indicator, Macroeconomic Dynamics, Vol. 7, No. 2, April, pp. 239-262.

Obstfeld M. and Tesar L. (2015), The Decline in Long-Term Interest Rates, Council of Economic Advisers. Posted on July 14, https://www.whitehouse.gov/blog/2015/07/14/decline-long-term-interest$\underline{\text { rates }}$

Orphanides, A.(2001), Monetary policy rules based on real-time data, American Economic Review, Vol. 91, No. 4, September, pp. 964-985.

Orphanides, A. and Williams, J. C. (2002), Robust monetary policy rules with unknown natural rates, Brookings Papers on Economic Activity, vol. 2, 63-145.

Panico C. (1987), Interest and Profits in the Theories of Value and Distribution, London, Macmillan Press.

Pasinetti L. (1966), Changes in the rate of profits and switches of techniques, Quarterly Journal of Economics, 80: 503-17. 
Petri F. (2004), General Equilibrium, Capital and Macroeconomics, Aldershot, Elgar.

Pivetti M. (1991), An Essay on Money and Distribution, London, Macmillan.

Pescatore A. and Turunen J. (2015), Lower for longer: Neutral Rates in the United States, IMF Working Papers, 15, 13.

Rachel, L. and Smith T.D.(2015), Secular Drivers of the Global Real Interest Rate, Bank of England Sta Working Paper No. 571, December.

Reifschneider D., Wascher W. and Wilcox D. (2013), Aggregate Supply in the United States: Recent Developments and Implications for the Conduct of Monetary Policy, Finance and Economics Discussion Series Divisions of Research \& Statistics and Monetary A airs, Federal Reserve Board, Washington, D.C., 77, November.

Ricardo D. (1951-1973), The Works and Correspondence of David Ricardo, Cambridge, Cambridge University Press.

Robertson D.H. ([1940] 1962), Essays in Monetary Theory, Asian Publishing House, Bombay.

Robertson D.H. (1963), Lectures on Political Economy, London, Macmillan.

Rochon L.P. and Setterfield M (2007), Interest rates, income distribution, and monetary policy dominance: Post-Keynesian and the "fair rate" of interest, Journal of Post-Keynesian Economics, 30, 1, 13.

Rogers, C. (1989), Money, Interest and Capital: A Study in the Foundations of Monetary Theory, Cambridge: Cambridge University Press

Rogers, C. (2018), The Conceptual Flaw in the Microeconomic Foundations of Dynamic Stochastic General Equilibrium Model, Review of Political Economy, 30(1), 72-83.

Rogoff, K. (2015), Debt Supercycle, Not Secular Stagnation, Vox: CEPR's Policy Portal, April 22. At: http://www.voxeu.org/article/debt-supercycle-not-secular-stagnation

Rosenberg, N. (1989), Inside the Black Box, Cambridge, Cambridge University Press.

Rotemberg, J.and Woodford M. (1999), Interest Rate Rules in an Estimated Sticky Price Model, in J. B. Taylor (ed.), Monetary Policy Rules, University of Chicago Press, Chicago, IL

Rotemberg J.J. and Woodford M. (1997), An optimization-based econometric framework for the evaluation of monetary policy, in Bernanke B.S. and Rotemberg J.J. (eds.), NBER Macroeconomic Annual 1997, MIT Press.

Rudebusch, G.D. (2001), Is the Fed Too Timid? Monetary Policy in an Uncertain World, Review of Economics and Statistics, 83 (2), 203-17.

Rudebusch, G.D. and Svensson L.E.O. (1999), Policy Rules for Inflation Targeting in Taylor J.B. (ed) Monetary Policy Rules University of Chicago Press, Chicago, pp. 203-247.

Schefold B. (1976), Different forms of technical progress, Economic Journal, 86: 806-19

Seccareccia, M. (1998), Wicksellian Norm, Central Bank Real Interest Rate Targeting and Macroeconomic Performance, in P. Arestis and M. Sawyer (eds.), The Political Economy of Central Banking, Cheltenham, UK: Edward Elgar, 1998, 180-198. 
Sims C.A. (1992), Interpreting the Macroeconomic Time Series Facts: The Effects of Monetary Policy, European Economic Review 36(5): 975-1011.

Smets, F., and Wouters, R. (2003). An estimated stochastic dynamic general equilibrium model of the euro area, Journal of the European Economic Association, 1(5), 1123-1175.

Smets, F., and R. Wouters (2007), Shocks and frictions in U.S. business cycles: A Bayesian DSGE approach," American Economic Review, Vol. 97, No. 3, June, pp. 586-606.

Smithin, J. (1994), Controversies in Monetary Economics: Ideas, Issues, and Policy. Aldershot, UK: Edward Elgar, 1994.

Smithin J., (1996), Macroeconomic Policies and the Future of Capitalism: the Revenge of the Rentiers and the Threat to Prosperity, Cheltenham, Edgar Elgar.

Smithin J. (2004), Interest Rate Operating Procedures and Income Distribution, in M. Lavoie and M. Seccareccia (eds.), Central Banking in the Modern World: Alternative Perspectives. Aldershot, UK: Edward Elgar, 2004, pp. 57-69.

Sraffa P. (1960), Production of Commodities by Means of Commodities, Cambridge, Cambridge University Press.

Stirati A. (2013), Alternative 'closures' to Sraffa's system: some reflections in the light of the changes in functional income distribution in the United States, in E.S. Levrero, A. Palumbo and A. Stirati, Sraffa and the Reconstruction of Economic Theory: Volume one. Theories of Value and Distribution, London, Palgrave Macmillan.

Stockhammer, E, and Sturn S. (2012), The Impact of Monetary Policy on Unemployment Hysteresis, Applied Economics, 44, 2743-2756

Summers, L.H. (2014), U.S. Economic Prospects: Secular Stagnation, Hysteresis, and the Zero Lower Bound. Business Economics, vol. 49 (April), pp. 6573.

Surico, P. (2008). The cost channel of monetary policy and indeterminacy, Macroeconomic Dynamics, 12, 724-735.

Taylor, J.B. (1993), Discretion versus Policy Rules in Practice, Carnegie-Rochester Conference Series on Public Policy 39, 195-214.

Taylor, J.B. (1999), A Historical Analysis of the Monetary Policy Rules, in J.B. Taylor (ed.), Monetary Policy Rules, Chicago, University of Chicago Press.

Taylor J.B. and Weiland V. (2016), Finding the equilibrium real interest rate in a fog of policy deviations, Institute for Monetary and Financial Stability, Working Papers Series no 103.

Thwaites G. (2015), Why are real interest rate so low? Secular stagnation and the relative prices of investment goods, Staff Working Papers 564, Bank of England, November.

Trehan, B. and Wu, T. (2007), Time-varying Equilibrium Real Rates and Monetary Policy Analysis, Journal of Economic Dynamics and Control, 31, 1564-1609.

Vines D. and Wills S. (2018), The financial system and the natural real rate of interest: towards a new benchmark theory model, Oxford Review of Economic Policy, 34, 1-2, 252-268. 
Yellen, Janet L. (2015) Normalizing Monetary Policy: Prospects and Perspectives. Speech delivered at the "The New Normal Monetary Policy," a research conference sponsored by the Federal Reserve Bank of San Francisco, San Francisco, California March 27.

Wicksell, K. ([1898], 1936), Interest and Prices: A study of the causes regulating the value of money, English Translation, London: Macmillan.

Wicksell, K., ([1901] 1934/35), Lectures on Political Economy, London, Routledge.

Wintr L., Guarda P. and Rouabah A. (2005), Estimating the natural rate of interest for the Euro area and Luxemburg, Cahiers d'etudes Working Paper, 15, Banque Central du Luxembourg, Eurosystem.

Woodford, M.(2003), Interest and Prices, Princeton University Press, Princeton, NJ.

Wray R.H. (2007), A Post Keynesian View of Central Bank Independence, Policy Targets, and the Rules Versus Discretion Debate, Journal of Post Keynesian Economics, Fall, 30 (1), 119-141.

Wu, T. (2005), Estimating the "Neutral”' Real Interest Rate in Real Time', Federal Reserve Bank of San Francisco Economic Letter 2005-27. 


\section{Appendix 1: The semi-structural approach of Laubach and Williams}

In Holston, Laubach and Williams (2016) the main equations of the New-Keynesian model outlined in Section 2 are put in the form

$$
\tilde{x}_{t}=a_{x 1} \tilde{x}_{t-1}+a_{x 2} \tilde{x}_{t-2}+a_{r} / 2 \sum_{j=1}^{2}\left(r_{t-j}-r_{t-j}^{n}\right)+\epsilon_{x t}
$$

$$
\pi_{t}=b_{\pi} \pi_{t-1}+\left(1-b_{\pi}\right) \pi_{t-2,4}+b_{y} \check{x}_{t-1}+\epsilon_{\pi t}
$$

[7] $\quad \check{x}_{t}=100\left(y_{t}-y_{p, t}\right)$

[8] $r_{t}^{n}=g_{t}+z_{t}$

$$
y_{p t}=y_{p, t-1}+g_{t-1}+\varepsilon_{p t}
$$

[10] $g_{t}=g_{t-1}+\epsilon_{g t}$

[11] $z_{t}=z_{t-1}+\varepsilon_{z t}{ }^{73}$

where the first two relations are observation equations and the others state equations that define the unobservable variables $y_{p}, g, r^{n}$ and $z .{ }^{74}$ In the $I S$ curve the expected rate of inflation is expressed as a function of past inflation (with $\pi_{t-2,4}$ as the mean of the second and fourth previous logarithms of the inflation rate), $\widetilde{x}_{t}$ and $\pi_{t}$ are log-variables, the shocks $\epsilon_{y t}$ and $\epsilon_{\pi t}$ leave the intercept of a simple monetary rule unchanged (namely, the NRI), and in equation [8] $\sigma$ is put equal to $1 .^{75}$ It is also assumed that potential output follows a random walk with stochastic drifts and that the error term persistently influences the rate of growth of natural output.

The Kalman filter is used to identify the parameters and estimate the unobserved variables ${ }^{76}$ and thus the NRI with the method of maximum likelihood. Since the estimates of the variances of $g$ and $z$ may bias towards zero and thus changes in the NRI hidden, the unbiased median

\footnotetext{
${ }^{73}$ For the meaning of the symbols, see equations [1] - [4]. In Laubach \& Williams (2003) the semi-structural model is similar. In the NRI equation, the term $c$ appears and the Phillips curve includes two variables concerning the shocks on imported and fuel prices. Moreover, to better identify output fluctuations, a relation between private work hours and the output gap is introduced.

${ }^{74}$ More generally, the state-space model is

$$
\begin{gathered}
y_{t}=A^{\prime} x_{t}+H^{\prime} \xi_{t}+v_{t} \\
\xi_{t}=F \xi_{t-1}+\varepsilon_{t}
\end{gathered}
$$

where $y$ and $x$ are the endogenous and exogenous variables respectively, $\xi$ is the state vector of the unobservable variables, $v$ and $\varepsilon$ are Gaussian and mutually non-correlated errors with mean zero and matrices $\mathrm{Q}$ and $\mathrm{R}$ of variances and covariances. Finally, matrices $A$ and $H$ have as their elements the coefficients of current and lagged exogenous and state variables.

${ }_{76}^{7 t}$ is in fact admitted that the relation between the NRI and the growth rate is not well identified in the data.

${ }^{76}$ On the Kalman filter, see Harvey(1989).
} 
estimator of Stock and Watson ${ }^{77}$ is used to get $\lambda_{g}=\frac{\sigma_{g}}{\sigma_{y_{p}}}$ and $\lambda_{z}=a_{r} \frac{\sigma_{z}}{\sigma_{\widetilde{x}}}$, whose values are imposed when estimating the parameters and variances of the output gap and potential output. With the Monte Carlo procedure, the uncertainty on the parameters is also taken into account, considering confidence intervals and the correspondent standard errors for the estimates of the unobservable variables (cf. Laubach \& Williams, 2001).

\footnotetext{
${ }^{77}$ After estimating using the Kuttner method the potential output by omitting the interest rate gap in equations [5] and [6], structural breaks are tested with the Wald statistic for each time $t$ in order to obtain $\lambda_{g}$ (the unbiased median noise of $g$ ) by using Stock and Watson statistic. Then $\sigma_{g}=\lambda_{g} \sigma_{y_{p}}$ is calculated. An analogous procedure is used to get the variance of $z$ and the final step is to estimate the whole model given the values of $\lambda_{g}$ and $\lambda_{z}$. The greater these values, the larger the uncertainty on the trend of $g$ and the unobserved process $z$.
} 